\title{
ECONOMIC IMPACTS \\ OF \\ GEOTHERMAL DEVELOPMENT \\ IN \\ HARNEY COUNTY, OREGON
}

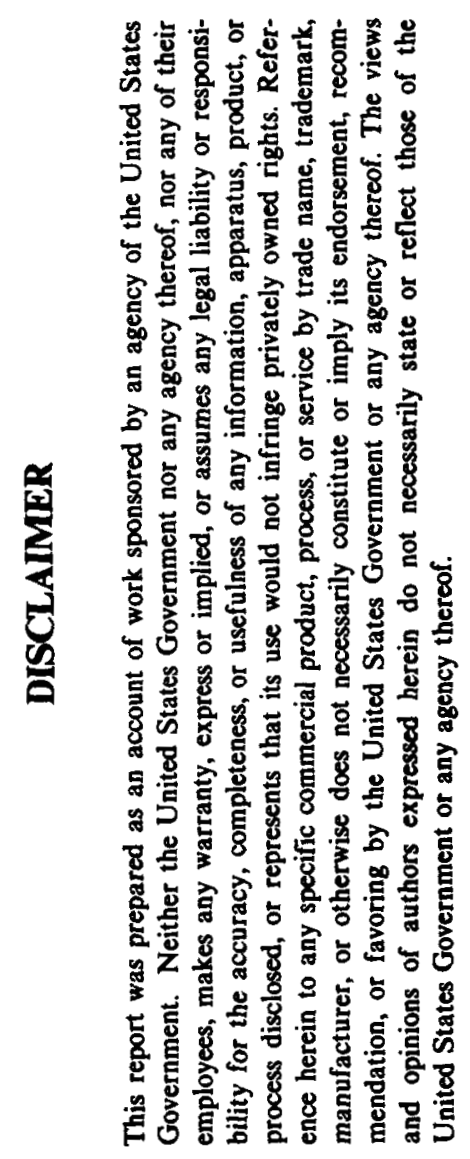

DECEMBER 1991

\author{
Alex Sifford \\ Kasi Beale \\ Oregon Department of Energy \\ Salem, Oregon
}

Prepared for the Bonneville Power Administration under Agreement No. DE-BI79-90BP07129 


\section{Disclaimer}

This report was prepared expressly for use by the Bonneville Power Administration. Neither the Oregon Department of Energy, Bonneville Power Administration, United States Department of Energy, nor any of their employees, nor any of their contractors, subcontractors or their employees, makes any warranty, express or implied, or assumes any legal liability or responsibility for the accuracy, completeness, or usefulness of any information presented. The views and opinions of authors expressed herein do not necessarily state or reflect those of the United States Government or any agency thereof. Reference herein to any specific product, process; or service by trade name, mark, or otherwise, does not constitute or imply its endorsement or recommendation or favoring by the United States Government or any agency thereof.

\section{Acknowledgement}

The authors appreciate input from Mark Dellinger of Lake County (Calif.) Planning Department, David McClain of California Energy Company, Kim Stukey of Pacific Gas \& Electric Company, and Jonathan Lesser of the Washington State Energy Office for his insightful economic analysis. 


\section{TABLE OF CONTENTS}

INTRODUCTION

page

BACKGROUND

Geothermal Compared to Conventional Plants

Development Phases \& Workforce

Exploration

Well Drilling

Steam/Water Gathering System

Power Plant Construction

Wellfield Maintenance

Power Plant Operation and Maintenance

HARNEY COUNTY PROJECT ASSUMPTIONS

Labor Requirements

Capital Requirements

Public Service Impacts

Costs

Revenues

$\begin{array}{lr}\text { ECONOMIC IMPACTS } & 19\end{array}$

Methodology $\quad 19$

$\begin{array}{ll}\text { Local Purchase Shares } & 20\end{array}$

$\begin{array}{ll}\text { Use of the IMPLAN Model } & 20\end{array}$

Assumptions

Impact Estimates

Response Coefficients

Impacts

$\begin{array}{lr}\text { CONCLUSIONS } & 27\end{array}$

$\begin{array}{ll}\text { REFERENCES } & 30\end{array}$

APPENDICES $\quad$ A-1 


\section{LIST OF TABLES \& FIGURES}

page

\section{TABLES}

1. Generating Plant Equipment Comparison

2. Range of Employee Estimates

3. Workforce \& Wage Projections

4. Geothermal Development Projections

5. State \& Local Projected Revenues

6. Local Share Estimates

7. Harney County Response Coefficients

8. Local Annual Economic Impacts

9. Local Annual Employment Impacts

10. Harney County Property Comparison

11. Harney County Revenue Comparison

\section{FIGURES}

1. Location of Harney County 


\section{INTRODUCTION}

This study provides local economic impact estimates for a 100 megawatt (MW) geothermal power project in Oregon. The hypothetical project would be in Harney County, shown in Figure 1. Bonneville Power Administration commissioned this study to quantify such impacts as part of regional confirmation work recommended by the Northwest Power Planning Council and its advisors. Harney County was chosen as it has both identified resources and industry interest.

Geothermal energy is defined as the heat of the earth. For purposes of this study, geothermal energy is heat capable of economically generating electricity (using available technology). That translates to steam or hot water over $300^{\circ} \mathrm{F}$.

Local economic impacts include direct, indirect, and induced changes in the local economy. Direct economic impacts result from the costs of plant development, construction, and operation. Indirect impacts result from household and local government purchases. Induced impacts result from continued respending as goods and services to support the households and local governments are purchased.

Employment impacts of geothermal development follow a pattern similar to the economic impacts. The workers associated with plant development bring their families to the area. Additional labor is required to provide support services for the new population. Local government services must also increase to support the new community growth and the geothermal plant itself. These changes yield indirect and induced employment impacts associated with the geothermal plant.

Public service impacts include costs such as education, fire protection, roads, waste disposal, and water supply. Experience at other geothermal areas is discussed in the project assumptions. The lesson is that negotiated agreements between developer and impacted public agency are a good tool to mitigate public costs associated with development. Public services are also affected by increased revenues from geothermal development. Property tax revenues increase significantly as plants begin producing electricity. The county also receives royalties from steam production. These revenue increases are assumed to translate into increased public services.

The background section first compares geothermal with conventional power plants. As presented, it is the fuel that primarily distinguishes geothermal from other power sources. Other aspects of development are similar to small scale conventional thermal sources. The process of geothermal development is then explained. Development consists of well drilling, gathering system construction, power plant construction, plant operation and maintenance, and wellfield maintenance. 
FIGURE 1

HARNEY COUNTY, OREGON

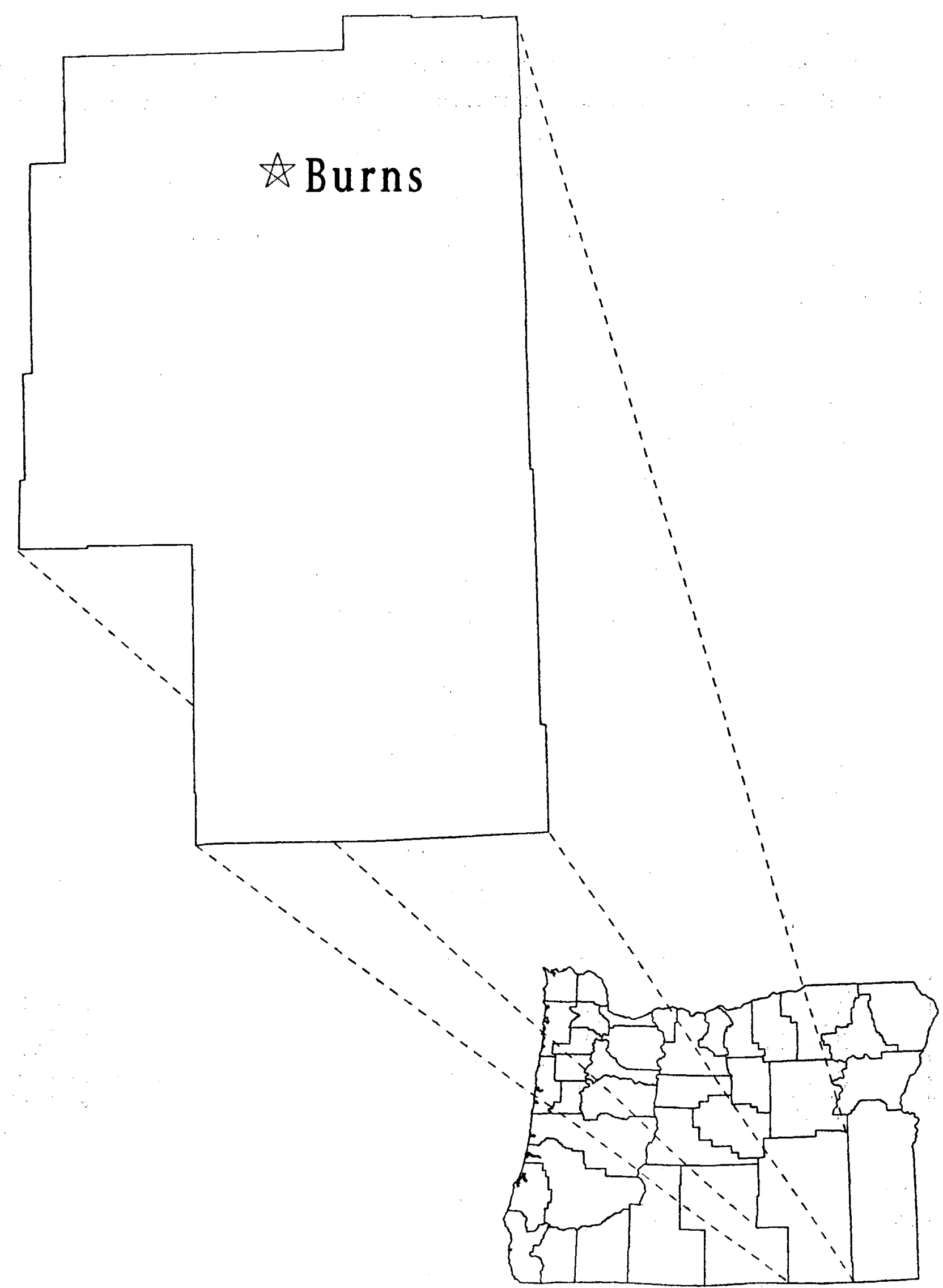


Based on the background information, labor, infrastructure and capital requirements of the hypothetical plant in Harney County, Oregon are described. The section first provides estimated labor requirements of each development phase. The construction phase is described in detail with regard to estimated work force, public service requirements, and construction costs. The last part of the development discussion addresses public service impacts of geothermal plant development.

The economic impacts section summarizes operating revenues, local royalty and tax payments, and local payroll of the hypothetical plant development specified for this study. In addition, both indirect and induced economic impacts associated with payments made by the plant owners to local governments and individuals are estimated.

The last section presents conclusions and a brief comparison with other industries in Harney County.

\section{BACKGROUND}

\section{Geothermal Compared to Conventional Plants}

Power plants convert fuels (or falling water) into electricity. Equipment necessary to create thermal energy or steam varies according to fuel type. Boilers are the most common device. Once steam is created, equipment that transforms thermal energy into electricity is used. Power generation components (turbine, generator, condenser, buildings, switchyard) are similar for all thermal power plants. Table 1 shows example power plant equipment groupings.

Fixed and variable costs differ among plant types. For example, hydroelectric dams have high capital costs and low fuel costs. In contrast, gas combustion turbines are relatively cheap to build and have high fuel costs.

TABLE 1

GENERATING PLANT EQUIPMENT COMPARISON

PLANT TYPE

Coal

Gas

Geothermal

Hydro

Nuclear

Wood
STEAM GENERATION

Boiler/Fluidized Bed

Boiler/gas turbine

Wells

Diversion, Dam

Reactor

Boiler/Fluidized Bed
POWER GENERATION

Turbine-generator

Turbine-generator

Turbine-generator

Turbine-generator

Turbine-generator

Turbine-generator 
All power projects require a large construction force of contractors and craftsman. This is then followed by a small plant staff that includes engineers, management/clerical, mechanics, and operators.

Geothermal power plants share some construction and operation characteristics common to all power plants. Where geothermal differs is source of fuel, and, to a lesser extent, size. The "fuel" is discussed below. Geothermal plants are typically less than $80 \mathrm{MW}$ due to past federal incentives. Clusters of modular plants e.g., 9 units at Coso and 26 units at ORMESA, are the latest trend. Given the combination of clustered plants and conservative reservoir development, new projects should mirror the hypothetical configuration of this report. Plants in this size range have the added benefits of matching load growth and reduced financial risks. Small power plants - regardless of fuel - offer reduced risks to ratepayer, developer, banker and utility alike.

As the above table shows, geothermal power plants get steam from the ground rather than a boiler. Thermal generating equipment - steam or hot water wells - is unique to geothermal power. An analogy would be the case of a gas power plant located next to the gas wells. Instead of gas (and its requisite combustion), geothermal steam comes out of the ground ready to drive a turbine and generate electricity. Pollution control equipment is only slightly different than from fossil fuel plants. The cost of geothermal plant pollution controls is similar to fossil fuel plants, and is included in cost estimates.

What further distinguishes geothermal power from other sources is the ability to account for steam either as fuel or as part of the plant. Geothermal power can be developed in either joint ventures of steam suppliers and utilities, or entirely by suppliers. That is, a utility can own and operate the power plant, buying steam from a supplier. Like buying fuel, the steam purchases would be expensed each year of operation. Or, a non-utility developer can build, own and operate both wells and plant. Electricity - not steam - would be sold to a utility. In accounting terms, the resource is expensed (as fuel) in the former example and capitalized (as plant) in the latter. For purposes of this report, we will assume an integrated non-utility operation, with both wells and plant under one owner.

For fossil fueled plants, a mineral royalty paid to the resource owner is part of the coal, gas or oil cost. Geothermal resources are treated similarly, with a royalty paid to the land or resource owner. For this study, royalty impacts on the local economy are significant because the resource is on federal land. Half of all federal royalties are returned to the state. Oregon passes the state share through to the county of origin. 


\section{Development Phases \& Workforce}

Exploring for and developing geothermal resources is very similar to oil and gas activities. (In fact, many developers started in the petroleum industry.) Today's geothermal firms coordinate resource exploration, oversee steam or hot water field development, maintain resource production and operate power plants.

Generating power from geothermal resources is typically done in several major stages. Environmental permitting occurs before each stage. Activities overlap: Some well drilling, steam line construction and plant building will occur concurrently. Some workers will move between these stages in the course of work. Typical stages are as follows:

- Exploring for the resource;

- Developing the wellfield \& gathering system;

- Constructing the power plant and related facilities;

- Operating and maintaining resource supplies; and

- Operating and maintaining plant facilities.

Much data is available for geothermal development at The Geysers in northern California. It is the largest developed geothermal field in the world, with about $1850 \mathrm{MW}$ of capacity currently. The first plant there was completed in 1960; the most recent in 1989. Many lessons are to be had from experience at The Geysers. This is combined with recent data from other newer developments in California, Nevada and Utah.

\section{Exploration}

Developing geothermal energy begins with the leasing of large tracts of land. Passive exploration includes geologic field surveys, mapping and analysis. Passive exploration occurs both before and after leasing, to reduce prospect area size. Exploratory drilling then follows, to determine the location, amount and quality of underground steam or hot water.

Generally, geothermal development companies maintain a small office in or near the county where development occurs to manage local operations. Staff size in local offices depends upon the amount of leased land, the extent and stage of development activities, and the level of subcontracted work. Geothermal developers have both office staff and field staff. Office staff may include clerical workers, administrative managers, professionals - such as geologists, earth scientists and environmental specialists and land agents. Permit compliance work is jointly performed by both corporate staff and contractors. One developer at The Geysers responsible for about $370 \mathrm{MW}$ of steam supplies and $55 \mathrm{MW}$ of power plants has a regional office with eight full time employees (Dellinger, 1990). Office personnel include 
environmental compliance staff. Some staff perform both office and field duties. Many workers manage a varying number of subcontractor activities e.g., preparing well pads and access roads, and drilling.

Information provided in Matthews, 1983 and subsequent plant permit documents indicates that local office employees of developers tend to be relatively long-term residents of the local area. Given the length of time between resource leasing and producing electricity, this makes sense. Many job skills required for a developers' office are available in the local labor pool. Those employees whose job skills require familiarity with geothermal resources or specialized technical knowledge may move into the local area for initial development activities and then remain.

Exploration is occurring now in Harney County, with insignificant local impacts. Geothermal company staff manage exploration from offices outside the county.

\section{Well Drilling}

Older geothermal plants in The Geysers require approximately 2,000,000 pounds of steam per hour to produce $110 \mathrm{MW}$ of power (Matthews, 1983). This equates to about $1,820,000$ pounds per hour for a $100 \mathrm{MW}$ plant. Newer Geyser plants require about 10 to 20 percent less steam per MW of capacity (Bloomquist, 1987; Nolte, 1987). Therefore, a new $100 \mathrm{MW}$ plant needs about 1,545,000 pounds per hour.

Approximately 20 to 30 wells provide steam for a $110 \mathrm{MW}$ power plant (Matthews, 1983). Prorating that range results in an estimate of 18 to 27 wells per $100 \mathrm{MW}$ plant. The range of resource flow and number of wells is due to variations in reservoir characteristics and steam quality. In simple terms, the hotter the steam or hot water, the less flow (and fewer wells) necessary to generate a fixed amount of power. Similarly, with greater flow of steam or hot water per well, fewer wells are needed to generate a fixed amount of power. Each well is unique and different steam characteristics for wells in the same leasehold are common. Without knowing specific resource parameters, we will assume the same well count of 18 to 27 total for this project.

Development of each well varies with depth and lithology, but at The Geysers it takes approximately 60 days with drilling crews working around the clock. Given high elevation locations in the Oregon Cascades, this drilling period may be extended seasonally. A typical drill rig is operated by four crews of 5 or 6 persons during each 24-hour period (USGS, cited in Matthews, 1983). Overseeing the rig.crew is a drilling superintendent employed by the geothermal developer. Thus, there is generally a total work force of about 25 persons associated with each drilling rig. 
Workers needed during the steam field development stage include drillers, derrickmen, roughnecks, roustabouts, floorhands, tool pushers, motor operators, welders, and rig superintendents (Cornelison, cited in Matthews, 1983). Most of the steam drilling work force at The Geysers do not belong to a craft union (Matthews, 1983).

Information provided by geothermal developers indicated that The Geysers drilling rig work force tends to be relatively long-term residents of the local area (Matthews, 1983). That drill rig workers moved into the area and stayed is logical, given the mature $(30+$ years $)$ development of that field. Although there may be changes within the personnel assigned to a drilling rig as workers move in and out, a minimum number of workers must be maintained for the rig to function. Once a particular rig and crew are active in an area, developers prefer to keep it busy there. The crews become familiar with the geologic idiosyncrasies of the area, and drilling equipment is prepared to address those characteristics.

For this study it is estimated that well drilling will employ an estimated 50 persons each year until 1998.

\section{Steam/Water Gathering System}

Once the majority of wells are complete and plant construction is underway, work begins on the steam/hot water gathering system. The gathering system is a pipeline network that collects the resource and delivers it to the plant. Typical gathering systems have two components: a short two phase resource (steam and hot water) line from the wells, and a longer steam line from separators to the plant. Steam line workers are different from drilling crews and plant constructors. The work force involved in pipeline construction may include plumbers, welders, pipefitters, foremen, and the laborers involved in preparing foundations and footings.

The number of workers constructing steam gathering systems varies with the pipeline design, routing and interconnection plan. The construction period may be a few weeks or a few months. The work force varied between as few as 4 or as many as 50 for a $110 \mathrm{MW}$ plant at The Geysers. Peak steam field and gathering system workers for the $27 \mathrm{MW}$ West Ford Flat plant completed in 1988 were estimated at 35 (Nolte, 1987). The amount of steam gathering system workers is not proportional to plant size. This phase can be either a short term, high worker number effort, or a longer term, low number effort. Weather, construction schedule and contract requirements all affect gathering system employee number.

The gathering system work force is less likely to be long-term local residents, since the duration of the work is short and months may elapse between jobs (Matthews, 1983). Pipeline gathering system workers will be needed shortly before completion of the first plant through startup of the last plant. This is 
estimated to be 20 workers for six months each year, for an average of 10 workers per year for 1995 through 1998.

\section{Power Plant Construction}

Once the first production wells are in, plant design begins. Power plant design is based on resource chemistry and enthalpy (heat content). Commercially available power plants range in size from 620 to 135,000 kilowatts. Geothermal plants in the range of 10,000 to 30,000 kilowatts, or 10 to 30 megawatts (MW) are common today. Also prevalent in the power industry is a trend towards more factory fabrication of components and less onsite erection New geothermal power plants specify modular components where feasible. Engineering and design can be reduced, the construction schedule shortened and revenues generated earlier as a result of modular components (Phair 1989). Equipment obtained as modular units for the Bear Canyon plant included air compressors \& accessories, electrical equipment modules, emergency diesel generator, fire water pumps $\&$ accessories, gas removal equipment, Stretford ${ }^{\mathrm{TM}}$ process and turbine generators (Phair 1989). Skid-mounted modular turbine generator units are available from several firms: Barber-Nichols Inc., ORMAT Energy Systems Inc. and Geothermal Power Co.

Geothermal plant sizes refer to net power at the utility (busbar) grid. Plants are typically designed and operated as baseload facilities; availability and capacity factors average over 90 percent for recent plants. For a background discussion see PURPA Influence on Contemporary Geothermal Plants, (Sifford, Bloomquist \& Geyer, 1987), and Innovative Design of New Geothermal Generating Plants, (Bloomquist, Geyer \& Sifford, 1989). Optimal economic development calls for baseload operation whenever possible. Typical "average megawatt" capacity for geothermal plants approaches net output. The latter term is commonly used, and will be throughout this report.

The average construction time for $55 \mathrm{MW}$ to $110 \mathrm{MW}$ geothermal plants in The Geysers was about 28 to 30 months (Matthews, 1983). Newer plants there have shortened this period considerably. The Bear Canyon plant was built in about 20 months instead of a projected 24 months (Phair 1989). The West Ford Flat plant came online only eight months after groundbreaking (Urbank, 1989). Other new plants in California, Nevada \& Utah had construction periods of less than two years due to significant shop fabrication of standard or similar units. The shortest construction period for a significant (7 MW) plant in an area similar to Harney County was 13 months, (Bloomquist, Geyer \& Sifford, 1989).

Construction of the power plant and related facilities is usually managed by one general contractor and several subcontractors. Construction of these facilities involves a succession of diverse tasks. Work tasks include construction of access roads; site clearance and preparation; placement of foundations and pads, construction of the power plant buildings; placement of the generating unit(s) and associated piping and 
electrical work; construction of related facilities, e.g., hydrogen sulfide abatement systems; air or water cooling systems; the switchyard and transmission system; and final site and facility finish work.

Workers needed for these tasks include pipefitters, welders, electricians, iron workers, carpenters, painters, equipment operators, concrete workers and finishers, teamsters and laborers, other manual labor skills, and supervisory and quality control inspection personnel. Many of the work tasks throughout the construction period are of relatively short duration, ranging between a few weeks and a few months. Some of the craft skills required are very specialized, and the number of workers in the state who are qualified to perform the skilled tasks is relatively small. However, a worker with a wide range of abilities and a high degree of skill in each of those various areas could maintain relatively continuous employment on a progression of geothermal power plants.

The peak work force during power plant construction is active on site after the foundations and pads are set, when work begins on generating unit(s) installation and mechanical and electrical connections. Once the major equipment is placed, construction continues simultaneously on the rest of the power plant structure and related facilities.

The majority of the construction work force is composed of electricians and pipefitters who are dispatched through union hiring halls. The number of electrical workers active during the peak period usually ranges between 5 and 35 but has been as many as 55 on a single project. The number of pipefitters active during the peak period may range between 6 and 50. It has been as high as 110 . Generally, this peak period extends out over one year, with the largest number of workers needed for six to eight months (Matthews, 1983). At new projects in California, Nevada and Utah, the choice of using union labor rests with the developer and construction firm.

Based on information plant developers provided the California Energy Commission, the maximum number of construction workers of a $110 \mathrm{MW}$ geothermal power plant ranged between 75 and 205 (Matthews, 1983; CEC, 1985). The wide variation may be due to both seasonal limits on earth movement work and phase of construction. Peak plant construction workers for the $27 \mathrm{MW}$ West Ford Flat plant completed in 1988 were estimated at 40 (Nolte, 1987). We therefore have an old range of numbers, and a recent point between them. The old range is .68 to 1.87 workers per MW. The West Ford Flat figure was 1.48. No straight line correlation is made for construction workers and plant capacity. Power sales schedule, seasonal slowdowns, financing and degree of shop fabrication all affect construction workforce levels.

Based on a range of 13 to 36 months, a 24 month construction period for the each plant is assumed. Workers would begin earth movement activities for the first plant in late 1993, but for ease of modelling, 
all construction is shown to begin in 1994. Plant building will be staged, but will include overlapping work whenever possible. It is expected that construction will be more efficient after the first plant is built.

\section{Wellfield Maintenance}

Once a geothermal power plant comes on line, it operates at full capacity all the time, barring technical or mechanical problems. Periodically throughout the lifetime of the power plant, the steam wells supplying the plant need to be redrilled to clear out obstructions or to regain full flow of the steam. New wells must be drilled if an existing supply well does not maintain sufficient output.

The work force needed to maintain an adequate resource supply for each well field and power plant is similar to the field development phase. A California Division of Oil and Gas representative in Santa Rosa believed that the average number of drilling rigs active in the Geysers in the early 1980 s will continue to be active for the lifetime of the geothermal resources in the Geysers. Steamfield work has shifted from developing new steam supplies to maintaining existing supplies. This makes sense as the last plant built there was in 1989. California Division of Oil and Gas staff estimated in Matthews that 9 to 12 rigs maintain steam flow at The Geysers. That requires a continuing work force of 225 to 300 . An estimated 8 field staff maintain over $370 \mathrm{MW}$ of Calpine Corp. wellfield at The Geysers (Dellinger, 1990). As discussed earlier, the steam field work force is expected to be drawn from long-term residents of the local area.

\section{Power Plant Operation and Maintenance}

In the final months of construction, personnel from the plant developer/operator begin testing equipment and systems. These workers may include power plant operators, plant engineers, electricians, instrument repairmen, and maintenance workers. Once the power plant comes on line, the permanent operation and maintenance work force maintains routine operations. Periodically, this work force may be supplemented by additional outside workers for facility overhaul and maintenance activities.

The number of workers that operate and maintain power plants and related facilities, (excluding the wellfield), varies by power plant owner/operator. The Pacific Gas \& Electric Company (PG\&E) operation and maintenance work force in 1981 for 17 Geysers plants (and $1135 \mathrm{MW}$ of net capacity) was about 130 (Matthews, 1983). At that time, PG\&E managed the plants from one administration center, the West Geysers Power Plant. In 1984 PG\&E created a separate satellite administration center, Geysers East, to manage growth in that part of the field. Geysers East had full duplicate staff of Geysers West. However, PG\&E recently reduced management at the Geysers East center and now operates the various units from Geysers West. Periodic checking of daily operations and necessary maintenance are performed by roving crews based at each administrative center. Each crew is responsible for two or more units. Current staff 
numbers about 210 persons, responsible for $1302 \mathrm{MW}$ of capacity (Stukey, 1991). This results in an average of .16 plant O\&M employees per MW. This number is low due to the enormous size of development there. PG\&E Geysers data provides the low end of plant O\&M staff levels.

In the last decade developers other than PG\&E began operating new plants in The Geysers. These developer/owners have initial operation and maintenance work forces of 10 to 20 workers per power plant. Fewer workers are required to operate and maintain subsequent power plants since the basic work force is already involved in their initial operation. This staff economy of scale holds true at the recently built Bear Canyon and West Ford Flat plants operated by Calpine Corp. Approximately 12 plant staff operate and maintain these plants (49 MW total), for an average of .24 employees per MW (Dellinger, 1990). Factoring in an additional 8 field staff results in an average of .41 total employees per MW. (This conservatively excludes additional, sizable steam reserves managed by the same field staff.)

The recently completed Coso development currently employs about 90 persons in plant operations and 170 people total (McClain, 1991). This results in an averages of .38 plant employees per MW and .73 total employees per MW. Table 2 provides ranges of employees by development phase. From these estimates Harney County assumptions were chosen.

TABLE 2

RANGE OF EMPLOYEE ESTIMATES

PHASE

Drilling

Wellfield Construction

Plant Construction

Total Construction

Wellfield Maintenance

Plant Operation

Total Operation
NUMBER PER MW

25 per rig

$.04-1.30$

$.68-1.87$

$.72-3.17$

25 per rig

$\frac{.16-.38}{41-.73}$

\section{NUMBER PER $25 \mathrm{MW}$}

25 per rig

$4-33$

$\frac{17-47}{21-79}$

25 per rig

$\frac{4-10}{10-18}$

Sources: Cited above

One reason for a range of worker estimates is economy of scale that affects plant personnel. Such ranges are not linear as plant sizes increase. A minimum number of employees is needed for any plant. Research shows that a geothermal plant $10 \mathrm{MW}$ in size requires almost as many operating staff as a plant two to five times that size (Bloomquist, Geyer \& Sifford, 1989). There is no record of the total number of geothermal industry workers. Neither is there sufficient accounting of actual numbers of workers employed in each 
stage of development. Contractual employees further compound estimates. However, there are at least some ranges of employees estimates, both with and without construction and field maintenance personnel.

\section{HARNEY COUNTY PROJECT ASSUMPTIONS}

Development assumptions are presented below. Information in this section is directly related to development phases. Cost and operation estimates are provided in detail. Research revealed unique factors regarding public service impacts in Oregon counties. These are discussed below.

Construction and operation assumptions for the hypothetical $100 \mathrm{MW}$ (net) project are as follows. Drilling for the first plant is assumed to begin in early 1993. Well drilling is assumed to average about 18 months per plant. (In reality, it will likely be longer than average for the first wells, and shorter than average for the last ones.) Given the uncertainty of Northwest resources, this report conservatively uses high well numbers. Approximately 25 wells - the midpoint of our 20 to 30 range - are needed to provide steam for a $100 \mathrm{MW}$ project. This total includes observation and injection wells. That same number of wells will be drilled again over the 30 year life of the power plant as replacement resources are needed.

The project will have four $25 \mathrm{MW}$ double flash or binary plants. Both technologies are capable of generating electricity from expected resources in Harney County's geothermal area (Pueblo Valley). Double flash refers to the number of separator stages needed to get usable steam. Hence, a double flash plant uses two separators to provide steam to the turbine. Binary refers to the use of a second working fluid, heated by geothermal steam or water, that drives the turbine.

The snow season in Pueblo Valley should not impede construction as at The Geysers. Although average elevation is about 4,000 feet above sea level, precipitation is only about 10 inches each year. It is therefore not necessary to expect seasonal delays in earth movement activities. A 24 month construction period per plant, conservative compared to most recent plants, is assumed for this analysis. The development scenario is presented over a six year period leading up to full operation at the end of 1998 . The plants will operate 90 percent of the year.

Most high temperature geothermal resources in the Pacific Northwest are on federal land. Such is the case at Pueblo Valley, excepting a small private inholding. Therefore, a 10 percent operating royalty will be collected by the federal government. Half of the royalties are given back to the state. All such (mineral) royalties are passed back to the counties in Oregon, per Oregon Revised Statutes 294.055. Royalties derive from steam - not power - production. Therefore, data from existing steam, supplier agreements are useful to determine plant assumptions. Steam cost values are estimated from two-party contractual data. Power plant steam use is taken from one of the most efficient plants at The Geysers. Royalty estimates are 
thus conservative. Less efficient plants may be built for slightly lower capital costs, but will experience higher operation, maintenance and royalty costs. Prudent developers will optimize steam efficiency with capital costs.

\section{Labor Requirements}

Table 3 shows estimated workforce and wage projections. The well drilling, pipeline gathering and plant construction crews will vary each year, depending on development stage. Well drilling will employ an estimated 50 persons each year until 1999. Plant construction staff will go from 10 in 1993 to 80 each year until 1998, when the last plant nears completion with only 40 workers. The same workforce would build each plant. Construction staff levels will remain constant (plus or minus a few supervisory personnel) after the first year.

Table 4 shows development projections from construction through the first years of operation. The first plant would begin commercial operation in January 1996. Over the power plant lifetime (typically 30 years), an additional 25 wells could be drilled to maintain the necessary supply of steam or hot water. One hundred percent reinjection of the resource would reduce this number to zero. Replacement well drilling will require workers only for a few months per year. This equates to about six full time employees maximum. At that time, drilling workers may be gradually drawn from the local labor pool. Wellfield maintenance employees start at 2 in 1995 and rise to 6 once replacement well drilling begins. The number of plant and wellfield operation staff will ramp up from 12 with the first plant to 20 at full operation. Operating personnel will be evenly divided between plant and wellfield for the first year. Purchase shares are discussed in a later section, with the breakout of local labor (and equipment) highlighted there.

For the complete $100 \mathrm{MW}$ development assumed for this study, 20 operation and maintenance workers are are forecast. This is low compared to the ranges in Table 2. One reason is the expectation that a single main control room will serve all plants. Direct employment estimates used in this analysis are intentionally conservative.

Construction worker wages vary between wellfield and plant. Given the specialized nature of well drilling, those staff wage levels are projected at $\$ 40,000$ per year. The average salary in Oregon for industrial building construction is about $\$ 30,000$ per year (Lux et al., 1989). Plant construction workers are not distinguished as union or non-union, but salaries are projected to closely match local union scale. For this study, above average plant construction salary rates of $\$ 34,000$ per year were chosen. Note that all wages forecast are average for many levels of workers and do not include benefits. Plant O\&M wages were estimated to be $\$ 40,000$ per year. 
WORKFORCE \& WAGE PROJECTIONS

$\begin{array}{llllllll}1993 & 1994 & 1995 & 1996 & 1997 & 1998 & 1999 & 2000\end{array}$

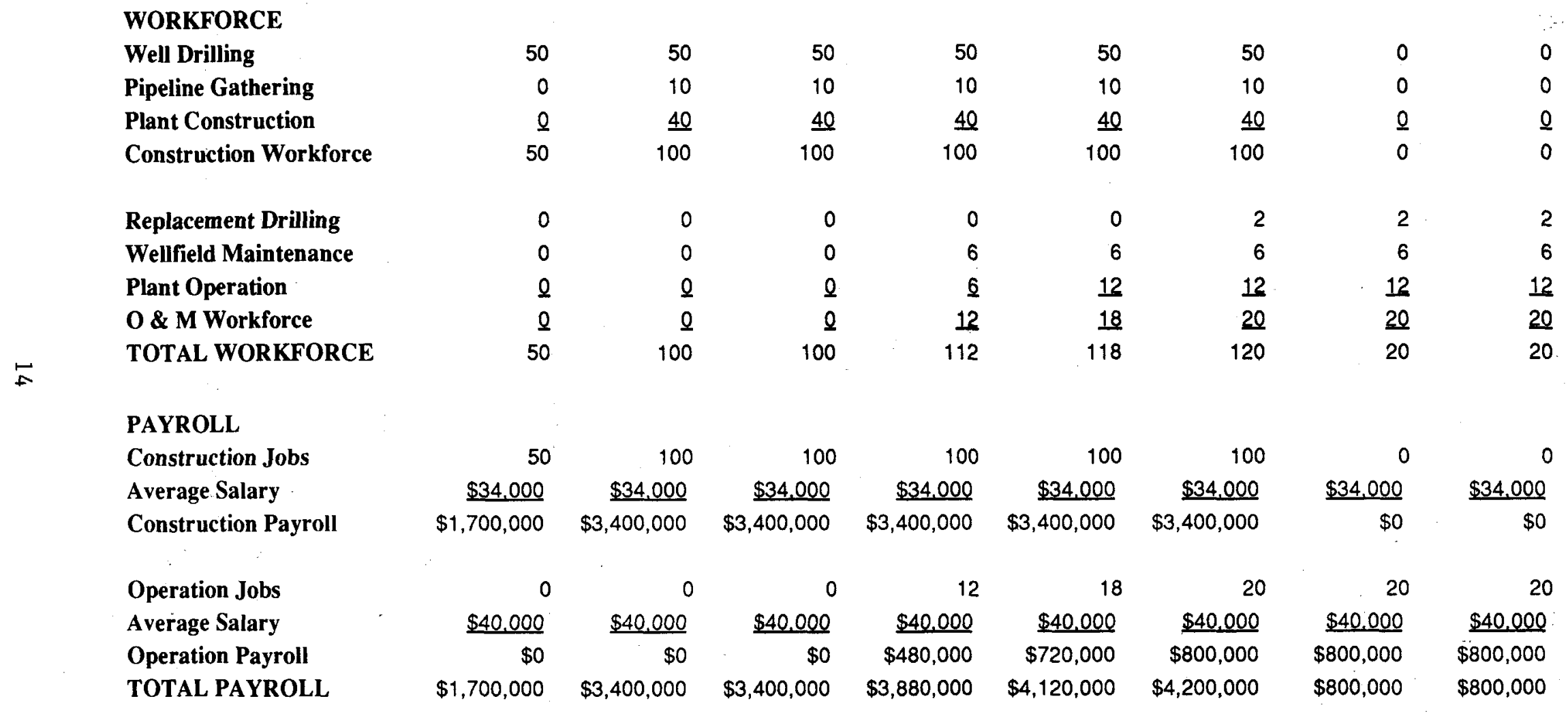




\section{GEOTHERMAL DEVELOPMENT PROJECTIONS}

\begin{tabular}{|c|c|c|c|c|c|c|c|c|}
\hline & 1993 & 1994 & 1995 & 1996 & 1997 & 1998 & 1999 & 2000 \\
\hline Plant Size (MW) & 0 & 0 & 0 & 25 & 50 & 75 & 100 & 100 \\
\hline Plant Value $(\$ / K W)$ & 2.800 & 2.800 & 2.800 & 2.800 & 2.800 & 2.800 & 2.800 & 2.800 \\
\hline CApital Value $(\$ 000)$ & 0 & 0 & 0 & 70,000 & 140,000 & 210,000 & 280,000 & 280,000 \\
\hline Property Tax Rate $(\$ / 000)$ & 21.04 & 22.50 & 20.00 & 17.50 & 15.00 & 15.00 & 15,00 & 15.00 \\
\hline Property Taxes & $\$ 0$ & $\$ 0$ & $\$ 0$ & $\$ 1,225,000$ & $\$ 2,100,000$ & $\$ 3,150,000$ & $\$ 4,200,000$ & $\$ 4,200,000$ \\
\hline Steam eff. (\#/kWh) & 14 & 14 & 14 & 14 & 14 & 14 & 14 & 14 \\
\hline Steam price $(\$ / 000 \#)$ & 1.45 & 1.45 & 1,45 & 1.45 & 1.45 & 1.45 & 1.45 & 1.45 \\
\hline Steam value $(\mathbf{\$} / \mathbf{k W h})$ & 0.0203 & 0.0203 & 0.0203 & 0.0203 & 0.0203 & 0.0203 & 0.0203 & 0.0203 \\
\hline Steam value per yr. & $\$ 0$ & $\$ 0$ & $\$ 0$ & $\$ 4,001,130$ & $\$ 8,002,260$ & $\$ 12,003,390$ & $\$ 16,004,520$ & $\$ 16,004,520$ \\
\hline Royalty Rate (\%) & 10.00 & 10.00 & 10.00 & 10.00 & 10.00 & 10.00 & 10.00 & 10.00 \\
\hline Royalty per year & $\$ 0$ & $\$ 0$ & $\$ 0$ & $\$ 400,113$ & $\$ 800,226$ & $\$ 1,200,339$ & $\$ 1,600,452$ & $\$ 1,600,452$ \\
\hline County $50 \%$ Share & $\$ 0$ & $\$ 0$ & $\$ 0$ & $\$ 200,057$ & $\$ 400,113$ & $\$ 600,170$ & $\$ 800,226$ & $\$ 800,226$ \\
\hline Power Sales $(\mathrm{kWh} / \mathrm{yr})$ & 0 & 0 & 0 & $197,100,000$ & $394,200,000$ & $591,300,000$ & $788,400,000$ & $788,400,000$ \\
\hline Power Price $(\$ / \mathbf{k W h})$ & 0.000 & $\underline{0.000}$ & $\underline{0.000}$ & $\underline{0.065}$ & $\underline{0.065}$ & $\underline{0.065}$ & $\underline{0.065}$ & $\underline{0.065}$ \\
\hline Gross Revenue per yr. & $\$ 0$ & $\$ 0$ & $\$ \$$ & $\$ 12,811,500$ & $\$ 25,623,000$ & $\$ 38,434,500$ & $\$ 51,246,000$ & $\$ 51,246,000$ \\
\hline Profit (@20\%) & $\$ 0$ & $\$ 0$ & $\$ 0$ & $\$ 2,562,300$ & $\$ 5,124,600$ & $\$ 7,686,900$ & $\$ 10,249,200$ & $\$ 10,249,200$ \\
\hline Corp. Tax Rate & $6.50 \%$ & $6.50 \%$ & $\underline{6.50 \%}$ & $6.50 \%$ & $6.50 \%$ & $6.50 \%$ & $6.50 \%$ & $6.50 \%$ \\
\hline Corp. Income Taxes & $\$ 0$ & $\$ 0$ & $\$ 0$ & $\$ 166,550$ & $\$ 333,099$ & $\$ 499,649$ & $\$ 666,198$ & $\$ 666,198$ \\
\hline Pers. Tax Rate & $10.00 \%$ & $10.00 \%$ & $10.00 \%$ & $10.00 \%$ & $10.00 \%$ & $10.00 \%$ & $10.00 \%$ & $10.00 \%$ \\
\hline Total Payroll \$/yr.) & $\$ 1,700,000$ & $\$ 3,400,000$ & $\$ 3,400,000$ & $\$ 3,880,000$ & $\$ 4,120,000$ & $\$ 4,200,000$ & $\$ 800,000$ & $\$ 800.000$ \\
\hline Income Taxes (\$/yr.) & $\$ 170,000$ & $\$ 340,000$ & $\$ 340,000$ & $\$ 388,000$ & $\$ 412,000$ & $\$ 420,000$ & $\$ 80,000$ & $\$ 80,000$ \\
\hline
\end{tabular}




\section{Capital Requirements}

Project cost assumptions are $\$ 2,800$ per net $\mathrm{kW}$, for $\$ 280,000,000$ total. The authors again use conservative assumptions for capital costs. Data from prior studies show a range of $\$ 1,550$ to $\$ 3,778$ per net kilowatt for recently built geothermal plants (Bloomquist, Geyer \& Sifford, 1989; OESI, 1991). Our estimate is broken down as $\$ 1,800$ for the plant and $\$ 1,000$ for the wells, on a per $\mathrm{kW}$ basis. While resources in Harney County appear easier to exploit, this report Total costs include engineering, construction, management, materials, and regulatory compliance. Construction costs include everything from preliminary earth movement through transmission line interconnection.

Little information is available on relative shares of labor, materials, and other costs as a portion of total plant capital costs. For the $20 \mathrm{MW}$ Bear Canyon plant, share estimates before completion were about $41 \%$ labor, $40 \%$ materials and 19\% other (Bloomquist, Geyer \& Sifford, 1989). We assume relatively high percentages of material to total costs For this study, labor cost share was estimated at twice the total payroll to account for fringe benefits, overhead and other labor-related costs generally billed as markups to labor. The total labor cost share projected in this report is about 16 percent. Materials cost are expected to be higher for this plant because of the availability of newer, more efficient technology, extensive use of modular components and because labor costs have not kept pace with inflation in recent years. For this study, materials cost share is estimated at about 60 percent and other costs at 24 percent. Materials are assumed to be spent in proportion to labor costs over the development time period.

The Harney geothermal site is close to an existing power line. Therefore, a two mile transmission line was chosen as representative for this study. Transmission costs equal about $\$ 220,000$ for materials plus $\$ 300,000$ for labor totalling $\$ 520,000$ (Hubsky, 1990). These costs are included in construction estimates, and are in 1991 dollars.

Capital necessary for this project will come from sources outside of Harney County. Financing geothermal power plants typically involves developer equity and lender debt packaged in a project finance loan or leveraged lease. Energy projects of this size obtain capital in either national or international markets (Bloomquist, Geyer \& Sifford, 1989).

\section{Public Service Impacts}

This section describes public sector costs and benefits associated with geothermal development. Development of the geothermal resources in Harney County will yield revenues for local government in the form of property taxes and resource royalties. It will also generate costs as the county will need to provide increased education services and infrastructure. Some costs may occur before revenues are 
generated. As noted below, recently developed techniques now allow fees to be collected prior to incurring public service costs.

\section{Costs}

Public service impacts are the costs of education, fire protection, roads, waste disposal, and water supply. Any large scale development will require some additional public services. Education and road impacts that adversely affected prior developments in California would be avoided in Harney County.

Education impacts are increased enrollment of project-related students (children of new workers) and potential new classroom space and buses. Schools in Oregon are financed by a combination of base level property tax levies and specific school bonding levies. Given the passage of Ballot Measure 5 in November 1990 and its attendant drop in school property tax rates, it is assumed that bond funding will no longer be available to fund increased services. Increased property taxes from geothermal development should raise school funding revenues. The critical factor is existing school enrollment: will new students exceed current capacity? Given the remote location, any students will likely either go to the boarding school at Crane or to a temporarily built school at Fields. The staged nature and small size of these projects is not expected to result in negative school capacity impacts. However, given the worst case scenario of maximum enrollment capacity, developers and the school district may choose to adopt a mitigation agreement providing for a temporary school at Fields.

Matthews, 1983 compares Geysers area school impact mitigation agreements. The one used by an 80 MW project there could be useful here. For a period of 8 years, the developer pays the school district an agreed upon amount. The developer and district then settle accounts between prepaid fees and property tax payments. The amount is calculated as follows:

The number of students times 55 square feet of classroom per student times the construction cost per foot, plus $\$ 1,000$ per student for buses.

Education impacts will be mitigated through increased property tax revenues, royalties returned to the county, negotiated agreement or perhaps some combination of the three sources.. Net cost to the County should approach zero, depending upon how much additional cost is borne by the developer.

Fire protection measures will likely be negotiated agreements with the Forest Service to build and maintain water storage facilities at the plant site. Temperature gradient drilling to date included fire protection measures, i.e., water tanks on site. This cost is included in plant capital costs. Net cost to the County should be zero. 
Roads in southern Harney County are the responsibility of both the state Highway Division and the county Roads Department. The state manages Highway 206 from Burns to Roaring Springs Ranch. The county manages Highway 206 from Roaring Springs Ranch to Denio, Nevada. That section of the highway was recently upgraded and paved (White, 1991). The remaining unimproved road from Fields to the Pueblo Valley site is about 5 miles long. This road is constructed to handle loaded cattle truck traffic. This will result in road development costs significantly lower than those experienced at The Geysers, where heavy duty roads did not already exist. About 75 percent of payments in lieu of taxes from federal agencies are dedicated to County road maintenance (White, 1991). County road costs are estimated at less than $\$ 1,000,000$ per year. Increased royalties to the county will cover those costs.

Preliminary indications are that the developer with prospects in Harney County prefers a binary power generation process. If this technology is used, no solid wastes would result as the power cycle is closed, i.e., all resources are returned to the reservoir. (Should a flash steam process be used, some solid wastes would result. Solid wastes from flash plants may be cooling tower sludge and sulfur cake from air pollution control and treatment systems (Felperin, 1989). It is expected that these solid wastes would be classified as hazardous wastes unless trace elements are washed out. In that case, the sulfur cake is classified as designated waste (Nolte, 1987). Waste disposal will consist of truck trips from the plant to a landfill near Arlington, Oregon. Arlington is the state's only commercial facility licensed to accept chemical hazardous waste.) It is premature to estimate numbers of such truck trips based on other plants because of the likelihood of binary cycle technology being used. Regardless, solid waste disposal costs will be borne by the developer.

Water supplies are primarily dust suppression and fire protection up until plant operation. At that time, a single large purchase of water from a market source (e.g.., a holder of a valid water right) will occur to fill the cooling system. Once plant operation begins, cooling water makeup will come from resource condensate. Net cost to the County will be zero.

\section{$\underline{\text { Revenues }}$}

State and local government revenue projections based on the above assumptions are included in the annual summary shown in Table 4. Capital costs, steam efficiency, and tax rates all affect the accuracy of these projections. Higher capital costs and lower steam efficiency would result in additional property taxes and royalties accruing to Harney County. Lower property tax rates will yield less revenues to the county. Building permit fees are not included in this work because they are "fees for service" (Prante, 1989). Taxes and royalties are the primary revenue sources, and are the biggest direct economic impacts to Harney County. This report uses the book value construction cost to base property taxes on. The 
property tax rate in Tables 4 and 5 reflects limitations imposed by the passage of Ballot Measure 5 in 1990. Current Harney County property tax rates are only slightly above newly mandated levels. Table 5 summarizes revenues to state and local governments at full operation.

\section{TABLE 5}

\section{STATE \& LOCAL PROJECTED REVENUES} 100 MW PLANT (1999)

\begin{tabular}{|lrr|}
\hline SOURCE & STATE & COUNTY \\
Federal Royalty (50\% county return) & $\$ 0$ & $\$ 800,226$ \\
Property Tax & $\$ 0$ & $\$ 4,200,000$ \\
Corporate Income Tax (6.5\% of Pretax Profit) & $\$ 666,198$ & $\$ 0$ \\
Personal Income Tax (10\% of wages) & $\$ 80,000$ & $\$ 0$ \\
TOTALS & $\$ 746,198$ & $\$ 5,000,226$ \\
\hline
\end{tabular}

\section{ECONOMIC IMPACTS}

\section{Methodology}

Estimation of local economic impacts associated with plant development is a three-phase task. First, the costs of building the plant and the returns to local governments associated with plant operation must be estimated for each year of plant development and for a typical year in which the plant is fully operational. These are based on the plant development assumptions and information described in the preceding section.

The second step in estimating local economic impacts is to identify or estimate the share of goods and services associated with plant development, construction and operation that are purchased locally, and the share of revenues that is returned to the local government. For this study local expenditures are those made within Harney County.

The last phase of assessing economic impacts is to estimate the indirect and induced impacts of the local expenditures and local government revenues identified in phases 1 and 2. An input/output model describes interactions between industries and estimates the impacts of changes in demand for goods and services provides this information. The model used for this study is the IMPLAN model developed by the U.S. Forest Service. Estimates of local expenditure shares and development of multipliers from the IMPLAN model are discussed below. 


\section{Local Purchase Shares}

The identification of local and non-local expenditure shares for wages paid and equipment purchased during plant development represents an estimate drawn from interviews with industry representatives, consultation with Washington State Energy Office researchers, and the author's knowledge of the industry. Data on payroll for geothermal plants is proprietary and there is little literature on the topic. The authors did find one vendor list that was useful in identifying sources of equipment. For Harney County we estimate 20 percent of the drilling crew, 40 percent of the pipeline gathering crew and 25 percent of construction labor will be local to the county. Non-local workforce includes workers commuting in from other counties and temporary workers that live elsewhere. Some workers may commute from Humboldt County Nevada (about 25 miles south), or send their wages back to whatever locale they originally came from. Few wage impacts will be concentrated in Harney County, as trade areas include Bend, Ontario, Boise, Idaho and even Winnemucca, Nevada for those workers. Table 6 shows local share estimates of labor and equipment used in this study: Because Harney County has very few industries producing materials and equipment needed for geothermal development, those respective local share estimates are assumed to be zero. In fact, some gravel or concrete supplies would likely come from local sources. This analysis estimate, at three percent, produces no appreciable indirect and induced impacts.

TABLE 6

LOCAL SHARE ESTIMATES

\begin{tabular}{|lcc|}
\hline & LOCAL & NON-LOCAL \\
\cline { 2 - 2 } MATERIALS AND EQUIPMENT & $0 \%$ & $100 \%$ \\
Drilling & $0 \%$ & $100 \%$ \\
Well field & $3 \%$ & $97 \%$ \\
Plant & & \\
LABOR & $20 \%$ & $80 \%$ \\
Drilling Crew & $40 \%$ & $60 \%$ \\
Pipeline & $25 \%$ & $75 \%$ \\
Construction & $100 \%$ & $0 \%$ \\
Operation & $100 \%$ & $0 \%$ \\
Maintenance &
\end{tabular}

\section{Use of the IMPLAN Model}

Input/output models estimate the direct, indirect and induced impacts of changes in final demand for a product or service. In the case of geothermal development, the direct impacts are the local employment and supply purchases associated with plant construction and maintenance. Indirect impacts are the employment and supply purchases associated with production of the supplies for plant development. For example, direct purchase of locally produced sheet metal for the plant indirectly generates additional 
purchases of supplies used to produce the sheet metal, such as raw metal and energy. The additional employment associated with production of the supplies for the geothermal plant also induces increased household spending as the employees spend their wages. Further information related to the IMPLAN model and data used in this study is included in Appendix A.

Total impacts are the sum of the initial and subsequent rounds of direct, indirect and induced impacts. In larger economies, total impacts are greater because in each successive round of respending, more money is respent locally. In smaller economies, fewer supplies and consumer goods are available locally. Total local impacts are reduced because purchases occur outside of the region.

The IMPLAN model lacks a specific sector that relates closely to geothermal development. The impact analysis conducted for this study is therefore based on patterns of household and local government spending, and purchases of construction materials generated by development. Most local impacts result from wages paid to plant construction workers and maintenance and operation staff, and from royalties and taxes paid to the Harney county government. Local government spending falls into two general categories, education and other local government services (including road and infrastructure development and other public services).

For this study, the IMPLAN model was used to develop response coefficients or estimates of the impacts of wages paid to local employees and the impacts of education and non-education related local government expenditures. The advantage to using response coefficients is that they represent the response - in both dollars and jobs - associated with an increase in spending valued in dollars. It therefore becomes unnecessary to convert values from current dollars to the 1982 base used by IMPLAN for analysis, and then convert back to current dollars for presentation. It also allows readers to differentiate between the impact estimate and the initial analysis of payroll and government spending associated with the project.

The IMPLAN model also provides information that can be used to generate a spending pattern for local purchases of construction materials. The "New Utility Structures" interindustry purchases identified by the model were used to help select sectors impacted by construction purchases. However, only 10 other local industries expected to be main recipients of geothermal development were included in the spending patterns used for this analysis. A portion of the construction expenditures were also allocated to the New Utility Structure sector. The response coefficient reflects both the author's judgement of spending patterns and the model's version. Sectors represented and their respective portion of local expenditures allocated to them are listed in Appendix D. 
Programs developed by Jonathan Lesser at the Washington State Energy Office were used to expedite extraction of the household and local government spending patterns. Appendices B, C and D include tabular presentations of spending patterns generated from the model. For this study, the mid-range spending level was used as the input in developing household expenditure response coefficients. The response coefficient or multiplier associated with spending in each category is generated and then applied to estimates of local payroll and government spending to calculate the impacts of geothermal development. Each expenditure pattern illustrates the average impact of project related spending in the Harney County economy. It describes the portion of each dollar of spending that goes to each industry in the local economy.

Before presenting the results of the IMPLAN analysis, it is important to review some of the assumptions associated with use of this model.

\section{Assumptions}

Using IMPLAN or any input/output model for impact analysis requires several assumptions:

1. The interindustry trade patterns provided in the model are a reasonable estimate of trade patterns in the county.

2. The total industry output (final demand components) and regional purchase coefficients used in the model reflect the county.

3. Relative prices of goods and services relevant to this analysis have not changed significantly since 1982. If, for example, the price of concrete has gone up more than the price of other goods since 1982, the model will yield somewhat inaccurate estimates of trade patterns that involve concrete.

4. The relative quantities of each input used in producing goods and services are consumed in fixed proportion to the quantity produced.

5 Activity in each project year is independent of activity in any other year. This assumption is required because IMPLAN is not a dynamic model -- it does not incorporated estimates of change during one year into estimates of change in subsequent years.

6. New employment generated by changes is assumed to be met via population increases. But the percentage unemployment in the county is assumed to stay the same.

The IMPLAN model yields estimated changes in output, income, employment and population. These results depend on assumptions about profit margins, population per employee, wages in each industry, and ratio of part-time and full time jobs in each industry. For this analysis, model assumptions were accepted and data provided with the model was used without modification, with a few exceptions which are discussed below. 


\section{Impact Estimates}

\section{Response Coefficients}

This section summarizes results of the impact analysis. Response coefficients (also called income multipliers) calculated for each component of the analysis are summarized below. Additional detail on response by major sector categories is included in Appendix D.

\section{TABLE 7}

\section{HARNEY COUNTY RESPONSE COEFFICIENTS} (Dollars or Jobs per Thousand Dollars of Increased Local Spending)

\begin{tabular}{|lrr|}
\hline & INCOME & EMPLOYMENT \\
Household spending & $\$ 251$ & 0.012 \\
Local Government Education Spending & $\$ 886$ & 0.023 \\
Other Local Government Spending & $\$ 628$ & 0.017 \\
\hline
\end{tabular}

Total impacts are calculated as the initial local response plus additional impacts estimated with the response coefficient. Thus the multipliers for household, government education, and other government spending are $1.251,1.886$, and 1.628, respectively. Calculations for household spending are explained below. The response coefficient is higher for education spending than for other services, implying that a greater share of purchases related to education are made locally. The direct impact of education related spending is about $\$ 759$; indirect and induced impacts bring the total to about $\$ 886$. For other local government services, the direct local impact is smaller, about $\$ 537$, so the total response coefficient is a lower $\$ 628$.

In developing the employment multipliers, the results of the IMPLAN model were adjusted to account for the author's disagreement with the model's assumptions. For education spending impacts, the model assumes fixed proportions of employment and other inputs. In reality, the school district is unlikely to hire as many new teachers as the model would indicate because the increase in population associated with geothermal development is fairly small. The county would probably hire a few teachers, and use the remainder of the new revenues for other improvements in the education system. The employment estimates were therefore adjusted downward for the government industry sector, which includes teachers' wages.

For employment impacts associated with household and other government services expenditures, the estimated employment impacts were checked against employment impacts calculated by dividing income impacts by $\$ 20,000$ annual salary. The results appear reasonably consistent, so IMPLAN's employment impacts were accepted for these categories. 


\section{Impacts}

Table 8 shows the calculation of local economic impacts associated with geothermal development. Local employment and equipment shares are shown. For every additional thousand dollars in household expenditures resulting from geothermal development payroll (take-home pay), about $\$ 251$ additional income accrues to businesses and individuals in the Harney County economy. Similarly, local government revenues respent on education generate about $\$ 886$ in additional local income for every $\$ 1000$ in spending. Other government services produce $\$ 628$ in direct, indirect and induced impacts for every $\$ 1,000$.

The response coefficients or multipliers are applied to the wage and local government values to compute estimated impacts. To compute total payroll impacts for each year, the estimated payroll associated with construction is first multiplied by the 75 percent local share. Then it is adjusted downward again to reflect take-home pay at 75 percent of local payroll. The household expenditure impacts are calculated as the multiplier times the household expenditures. The total payroll impacts are the sum of household expenditure impacts and local payroll.

To compute the impacts of local government spending, the local government revenues are shared out between ( 67 percent) education related spending and (33 percent) spending for other government services. These share were prorated from data provided by the Harney County Assessor's Office. The multiplier for each type of government spending is one plus the response coefficient because the impacts include the initial payments to local government plus the response to local government spending.

As shown in Table 8, there are payroll impacts but no local government spending impacts during the first three years of geothermal development. As the first plant comes on line in 1996, royalties and taxes are paid to the county government. Local government revenues and impacts increase until 1999 and then stabilize. Payroll impacts decline to full plant operation levels in 1999.

Employment impacts are calculated in Table 9. For each category, the expenditure change is multiplied by the jobs multiplier to yield estimated direct, indirect, and induced employment changes. The total employment impacts include the employment directly associated with geothermal development, plus the employment impacts for each category except construction materials. 


\section{LOCAL ANNUAL INCOME IMPACTS}

TOTAL PAYROLL

LOCAL PAYROLL (75\%)

HOUSEHOLD EXP. (75\%)

HOUSEHOLD INCOME MULTTPLIER

HOUSEHOLD EXP. IMPACTS

TOTAL PAYROLL IMPACTS

PROPERTY TAXES

FEDERAL ROYALTY SHARE (50\%)

EDUCATION SHARE T\&R (67\%)

EDUCATION MULTIPLIER

EDUCATION IMPACTS

OTHER SERVICES SHARE T\&R (33\%)

OTHER SERVICES MULTIPLIER

OTHER SERVICES IMPACTS

TOTAL LOCAL IMPACTS

$\begin{array}{llllllll}1993 & 1994 & 1995 & 1996 & 1997 & 1998 & 1999 & 2000\end{array}$

\begin{tabular}{|c|c|c|c|c|c|c|c|}
\hline 1993 & 1994 & 1995 & 1996 & 1997 & 1998 & 1999 & 2000 \\
\hline$\$ 1.700 .000$ & $\$ 3,400,000$ & $\$ 3,400,000$ & $\$ 3.880 .000$ & $\$ 4.120 .000$ & $\$ 4.200,000$ & $\$ 800.000$ & $\$ 800.000$ \\
\hline$\$ 1,275,000$ & $\$ 2,550,000$ & $\$ 2,550,000$ & $\$ 2,910,000$ & $\$ 3,090,000$ & $\$ 3,150,000$ & $\$ 600,000$ & $\$ 600,000$ \\
\hline$\$ 956,250$ & $\$ 1,912,500$ & $\$ 1,912,500$ & $\$ 2,182,500$ & $\$ 2,317,500$ & $\$ 2,362,500$ & $\$ 450,000$ & $\$ 450,000$ \\
\hline 0.25 & 0.25 & 0.25 & 0.25 & 0.25 & 0.25 & 0.25 & 0.25 \\
\hline$\$ 240.019$ & $\$ 480.038$ & $\$ 480.038$ & $\$ 547.808$ & $\$ 581.693$ & $\$ 592.988$ & $\$ 112.950$ & $\$ 112950$ \\
\hline $1,515,019$ & $\$ 3,030,038$ & $\$ 3,030,038$ & $\$ 3,457,808$ & $\$ 3,671,693$ & $\$ 3,742,988$ & $\$ 712,950$ & $\$ 712,950$ \\
\hline$\$ 0$ & $\$ 0$ & $\$ 0$ & $\$ 1,225,000$ & $\$ 2,100,000$ & $\$ 3,150,000$ & $\$ 4,200,000$ & $\$ 4,200,000$ \\
\hline$\$ 0$ & $\$ 0$ & $\$ 0$ & $\$ 200,057$ & $\$ 400,113$ & $\$ 600,170$ & $\$ 800,226$ & $\$ 800,226$ \\
\hline$\$ 0$ & $\$ 0$ & \$o & $\$ 1,425,057$ & $\$ 2,500,113$ & $\$ 3,750,170$ & $\$ 5,000,226$ & $\$ 5,000,226$ \\
\hline$\$ 0$ & \$o & \$o & $\$ 954,788$ & $\$ 1,675,076$ & $\$ 2,512,614$ & $\$ 3,350,151$ & $\$ 3,350,151$ \\
\hline 1.89 & 1,89 & 1.89 & 1.89 & 1.89 & 1.89 & 1.89 & 1.89 \\
\hline$\$ 0$ & $\$ 0$ & $\$ 0$ & $\$ 1,800,730$ & $\$ 3,159,193$ & $\$ 4,738,789$ & $\$ 6,318,386$ & $\$ 6,318,386$ \\
\hline$\$ 0$ & $\$ 0$ & \$o & $\$ 470,269$ & $\$ 825,037$ & $\$ 1,237,556$ & $\$ 1,650,075$ & $\$ 1,650,075$ \\
\hline 1.63 & 1,63 & 1.63 & 1.63 & 1.63 & 1.63 & 1.63 & 1.63 \\
\hline$\$ 0$ & $\$ 0$ & $\$ 0$ & $\$ 765,597$ & $\$ 1,343,161$ & $\$ 2,014,741$ & $\$ 2,686,321$ & $\$ 2,686,321$ \\
\hline .5 & 038 & $\$ 3,030,038$ & $\$ 7,449,191$ & $\$ 10,674,159$ & $\$ 14,246,687$ & $\$ 14,717,883$ & $\$ 14,717,883$ \\
\hline
\end{tabular}


TABLE 9

\section{LOCAL ANNUAL EMPLOYMENT IMPACTS}

GEOTHERMAL EMPLOYMENT HOUSEHOLD EXPENDITURES JOBS MULTIPLIER (JOBS/ $\$ 1,000,000)$ HOUSEHOLD EXP. JOB IMPACTS

\section{EDUCATION SHARE T\&R}

JOBS MULTIPLIER (JOBS $\$ 1,000,000)$

EDUCATION JOB IMPACTS

๙ OTHER SERVICES SHARE T\&R JOBS MULTIPLIER (JOBS $/ \$ 1,000,000)$ OTHER SERVICES JOB IMPACTS

TOTAL EMPLOYMENT IMPACTS

\begin{tabular}{|c|c|c|c|c|c|c|c|}
\hline 1993 & 1994 & 1995 & 1996 & 1997 & 1998 & 1999 & 2000 \\
\hline 50 & 100 & 100 & 112 & 118 & 120 & 20 & 20 \\
\hline$\$ 956,250$ & $\$ 1,912,500^{\circ}$ & $\$ 1,912,500$ & $\$ 2,182,500$ & $\$ 2,317,500$ & $\$ 2,362,500$ & $\$ 450,000$ & $\$ 450,000$ \\
\hline 12 & 12 & 12 & 12 & 12 & 12 & 12 & 12 \\
\hline 11 & 22 & 22 & 25 & 27 & 27 & 5 & 5 \\
\hline$\$ 0$ & $\$ 0$ & $\$ 0$ & $\$ 954,788$ & $\$ 1,675,076$ & $\$ 2,512,614$ & $\$ 3,350,151$ & $\$ 3,350,151$ \\
\hline 23 & $\underline{23}$ & 23 & $\underline{23}$ & 23 & 23 & 23 & 23 \\
\hline 0 & 0 & 0 & 22 & 39 & 58 & 77 & 77 \\
\hline$\$ 0$ & $\$ 0$ & $\$ 0$ & $\$ 470,269$ & $\$ 825,037$ & $\$ 1,237,556$ & $\$ 1,650,075$ & $\$ 1,650,075$ \\
\hline 17 & 17 & 17 & 17 & 17 & 17 & 17 & 17 \\
\hline$\overline{0}$ & 0 & $\overrightarrow{0}$ & 8 & 14 & $\overline{21}$ & 28 & 28 \\
\hline 61 & 122 & 122 & 167 & 197 & 226 & 130 & 130 \\
\hline
\end{tabular}




\section{CONCLUSIONS}

It is useful to first clarify limitations of the study. This study presents economic impact estimates of geothermal development in Harney County. It is not a cost/benefit analysis. No comprehensive comparison of quantifiable project costs and benefits is provided. The public service discussion addressed some environmental impacts, but a comprehensive analysis is beyond the scope of this study. No attempt was made to assess the value of geothermal development compared to other types of electric resources, whether efficiency or new generation.

The primary effects of geothermal development - or any large construction project - on the local economy are income associated with wage payments, and income from local purchases of construction material. The next big direct impact is revenue for the County government from property taxes and royalties. State level revenue impacts occur through income taxes. The multipliers for household and local government expenditures estimated for this analysis are equally applicable to any source of payroll or county government revenues.

It is instructive to compare estimated geothermal economic impacts with existing industry in Harney County. Harney County's total 1990 assessed tax base was $\$ 3,164,505,791$ (Assessors Office, 1991). Table 10 compares projected geothermal property values with the top five current (private) property owners in Harney County.

TABLE 10

\begin{tabular}{|lc|}
\multicolumn{1}{c}{ HARNEY COUNTY PROPERTY COMPARISON } \\
\hline OWNER & 1990 ASSESSED VALUE \\
PACIFICORP & $\$ 31,603,800$ \\
TETON LAMINATES & $\$ 16,045,220$ \\
SNOW MTN. PINE & $\$ 9,296,610$ \\
& \\
Geothermal Plant - 25 MW & $\$ 70,000,000$ \\
Geothermal Plant - 100 MW & $\$ 280,000,000$ \\
\hline
\end{tabular}

Source: Harney County Assessor's Office

Simple multiplication is used between $25 \mathrm{MW}$ plant costs and those for a $100 \mathrm{MW}$ plant. A $25 \mathrm{MW}$ geothermal development would represent a little over 2 percent of the total current base and the full 100 MW about nine percent. To put it in perspective, the combined value of Pacific Northwest Bell and Pacificorp property is roughly equal to one $25 \mathrm{MW}$ plant in value. A $100 \mathrm{MW}$ project would be four times 
the combined value of Pacific Northwest Bell and Pacificorp property in Harney county. Any investment of this size - regardless of what the project produces - would become the largest development in Harney County.

Table 11 compares projected geothermal revenues with recent payments to Harney County. Harney County's major industries are timber, agriculture and tourism. Principal products are lumber, moulding, particleboard, plywood, cattle and potatoes. The largest county landowner is the federal government. As shown, only returned receipts from sales of federal timber represent a comparable revenue source for Harney County. That portion of timber sale receipts paid to the County is about $\$ 4.1$ million. (Additional income from National Forest lands is about $\$ 285,000$. It includes land use, recreation, power, minerals, user fee and grazing fee payments.)

On an employment basis, the long-term impacts of geothermal power development are small compared to existing industries. The trend toward modular design and shop fabrication results in a smaller construction workforce compared to both early geothermal projects and other (recent) thermal plants. Geothermal development would lead to only marginal increases in total employment once the construction phase concludes. It should be noted that plant operation and maintenance jobs would pay relatively well. This results in greater economic impacts per job.

One reason impacts are not greater is the lack of a geothermal industry infrastructure in Harney County. If major geothermal resource development were to occur over time, more of the materials and labor for development would come from local sources. Findings presented here are also sensitive to plant capital costs, steam efficiency, tax rates and the health of the economy in Harney County. Other similar developments in the region may also affect these projections. 
TABLE 11

\section{HARNEY COUNTY REVENUE COMPARISON}

\begin{tabular}{lr|}
\hline TAXPAYER & 1990 PAYMENT \\
MALHEUR \& OCHOCO NATIONAL & $\$ 4,318,670$ \\
FOREST (Payments in lieu of taxes) & $\$ 777,717$ \\
PACIFICORP & $\$ 328,000$ \\
BLM (Payments in lieu of taxes) & \\
Geothermal Plant - 25 MW & \\
Property Taxes & $\$ 1,225,000$ \\
Royalties & $\$ 200,057$ \\
Total & $\$ 1,425,057$ \\
$\begin{array}{l}\text { Geothermal Plant - 100 MW } \\
\text { Property Taxes } \\
\text { Royalties } \\
\text { Total }\end{array}$ & 0 \\
\hline
\end{tabular}

Sources: Harney County Assessor's Office National Forest staff 


\section{References}

Bloomquist, R.G., J. Geyer \& A. Sifford, 1989, Innovative Design of New Geothermal Generating Plants, DOE/BP-13609-5, prepared for the Bonneville Power Administration under agreement no. DE-AI79-878P66141, Portland, OR.

Bloomquist, R.G., J. Geyer \& A. Sifford, 1987, PURPA Influence on Contemporary Geothermal Power Plants, Case Studies 1986, DOE/BP-13609-4, prepared for the Bonneville Power Administration under agreement no. DE-AI79-878P66141, Portland, OR.

Bloomquist R.G., et. al., 1985, Evaluation \& Ranking of Geothermal Resources for Electrical Ranking or Offset in Idaho, Montana, Oregon \& Washington, DOE/BP-13609-1, prepared for the Bonneville Power Administration under agreement no. DE-AI79-83PBI3609, Portland, OR.

California Energy Commission, 1985, Preliminary Staff Assessment for Central California Power Agency No. I Coldwater Creek Geothermal Power Plant, 84-AFC-2, Sacramento, CA

California Energy Company Inc., 1988, Third Quarter 1988 Report, San Francisco, CA

Dellinger, M., Personal Communication, Lake County Planning Department, December 11, 1990

Felperin, Daniel J., 1989, Geothermal Sulfur, Marketing Strategies, Geothermal Resources Council Transactions, Vol. 13, Davis, CA

Hubsky, M., 1991, Personal communication with J. Lesser, WSEO, Olympia, WA

Matthews, Kathryn M., 1983, Public Service Impacts of Geothermal Development, Final Staff Report, P700-83-004, California Energy Commission, Sacramento, CA

Lux, K. et. al., 1989, Oregon Covered Employment and Payrolls by Industry and County 1988, Employment Division, Oregon Department of Human Resources, Salem, OR

Means Facility Cost Data, 1990, R. S. Means Co., Kingston, MA

Means Building Cost Data, 1990, R. S. Means Co., Kingston, MA.

OESI Power Corporation, 1991, Common Stock Prospectus, Kidder, Peabody \& Co., New York, NY

Phair, K. A., 1989, Modular Design and Construction At The Bear Canyon 20 MW Power Plant, Geothermal Resources Council Transactions, Vol. 13, Davis CA

Prante, Lois J., 1989, Letter to John Geyer, Deschutes County Commissioners, February 8, 1989, Bend, OR

Nolte and Associates, 1987, Executive Summary Draft Supplemental Environmental Impact Report West Ford Flat Power Plant Project, Freeport-McMoran Resource Partners/Geysers Geothermal Co., Santa Rosa, CA 
Schoonmaker, James L., 1989 The Coso Geothermal Power Projects, Geothermal Resources Council Transactions, Vol. 13, Davis CA

Stukey, K., Personal Communication, West Geysers Power Plant, Healdsburg, CA., Pacific Gas \& Electric Company, January 23, 1991

Urbank, K. F., 1989, Design and Construction Of The West Ford Flat Power Plant At The Geysers, Geothermal Resources Council Transactions, Vol. 13, Davis CA

White, D., 1991 Persosnal Communication, Harney County Court, Burns OR, February 20, 1991 


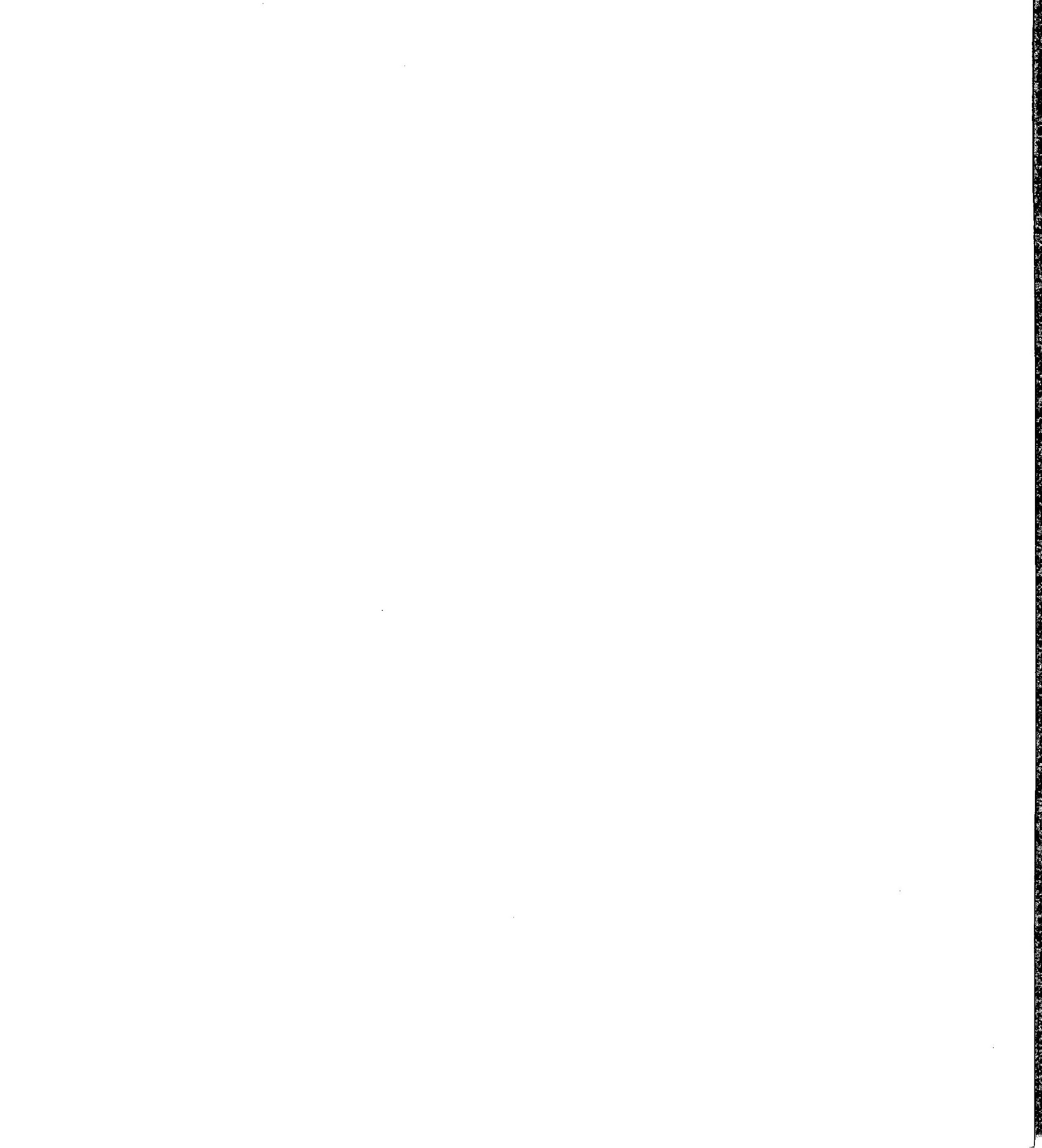




\section{APPENDIX A}

\section{IMPLAN MODEL SUMMARY}

IMPLAN is a secondary-data input/output model that translates national level information about the goods and services purchased and products sold by each industry in the economy into state- or county-level input output models using local economic information. The model is based on industry production functions estimated in 1977 by the U.S. Bureau of Economic Analysis. The 1977 model has been price-updated to 1982. In other words, trade between industries and purchases of labor and other services reflects patterns that occurred in 1977, translated into 1982 dollars. In using the model the assumption is made that interindustry trade is reasonably comparable to 1977 trade patterns. The IMPLAN software allows for adjustments to most of the data and industry structures where more current information is available. However, large scale revisions of the basic model were beyond the scope of this study. For this analysis, IMPLAN's national data and Oregon and Harney County data previously reviewed by Alan Fox, an IMPLAN consultant, formed the basis for the Harney model. The data was provided as part of an IMPLAN training workshop. 


\section{APPENDIX B}

\section{HARNEY COUNTY PERSONAL CONSUMPTION EXPENDITURE PATTERNS FRACTION OF TOTAL CONSUMER SPENDING WITHIN REGION}

\begin{tabular}{|c|c|c|c|c|}
\hline INDUSTRY & & PCE-LOW & PCE-MED & $\mathrm{PCE}-\mathrm{HI}$ \\
\hline DAIRY FARM PRODUCTS & 1 & .00076 & .00061 & .00044 \\
\hline POULTRY AND EGGS & 2 & .00003 & .00002 & .00002 \\
\hline RANCH FED CATTLE & 3 & .00000 & .00000 & .00000 \\
\hline RANGE FED CATTLE & 4 & .00001 & .00001 & .00001 \\
\hline CATTLE FEEDLOTS & 5 & .00005 & .00005 & .00004 \\
\hline SHEEP, LAMBS AND GOATS & 6 & .00000 & .00000 & .00000 \\
\hline HOGS, PIGS AND SWINE & 7 & .00000 & .00000 & .00000 \\
\hline OTHER MEAT ANIMAL PRODUCTS & 8 & .00000 & .00000 & .00000 \\
\hline MISCELLANEOUS LIVESTOCK & 9 & .00036 & .00034 & .00026 \\
\hline FOOD GRAINS & 11 & .00000 & .00000 & .00000 \\
\hline FEED GRAINS & 12 & .00000 & .00000 & .00000 \\
\hline HAY AND PASTURE & 13 & .00006 & .00009 & .00010 \\
\hline GRASS SEEDS & 14 & .00000 & .00000 & .00000 \\
\hline VEGETABLES & 18 & .00242 & .00199 & .00147 \\
\hline SUGAR CROPS & 19 & .00000 & .00000 & .00000 \\
\hline MISCELLANEOUS CROPS & 20 & .00000 & .00000 & .00000 \\
\hline FOREST PRODUCTS & 22 & .00001 & .00001 & .00001 \\
\hline GREENHOUSE AND NURSERY PRODUCTS & 23 & .00083 & .00098 & .00133 \\
\hline AGRICULTURAL， FORESTRY， FISHERY & 26 & .00013 & .00013 & .00013 \\
\hline LANDSCAPE AND HORTICULTURAL SERV & 27 & .00003 & .00002 & .00002 \\
\hline CRUSHED AND BROKEN LIMESTONE & 45 & .00000 & .00000 & .00000 \\
\hline CONSTRUCTION SAND AND GRAVEL & 48 & .00000 & .00000 & .00000 \\
\hline BENTONITE & 50 & .00000 & .00000 & .00000 \\
\hline MISC. NONMETALLIC MINERALS, N.E. & 58 & .00000 & .00000 & .00000 \\
\hline NEW RESIDENTIAL STRUCTURES & 66 & .00000 & .00000 & .00000 \\
\hline NEW INDUSTRIAL AND COMMERCIAL BU & 67 & .00000 & .00000 & .00000 \\
\hline NEW UTILITY STRUCTURES & 68 & .00000 & .00000 & .00000 \\
\hline NEW HIGHWAYS AND STREETS & 69 & .00000 & .00000 & .00000 \\
\hline NEW FARM STRUCTURES & 70 & .00000 & .00000 & .00000 \\
\hline NEW MINERAL EXTRACTION FACILITIE & 71 & .00000 & .00000 & .00000 \\
\hline NEW GOVERNMENT FACILITIES & 72 & .00000 & .00000 & .00000 \\
\hline MAINTENANCE AND REPAIR, RESIDENT & 73 & .00000 & .00000 & .00000 \\
\hline MAINTENANCE AND REPAIR OTHER FAC & 74 & .00000 & .00000 & .00000 \\
\hline MAINTENANCE AND REPAIR OIL AND G & 75 & .00000 & .00000 & .00000 \\
\hline SMALL ARMS & 79 & .00000 & .00000 & .00000 \\
\hline SMALL ARMS AMMUNITION & 80 & .00000 & .00000 & .00000 \\
\hline MEAT PACKING PLANTS & 82 & .00285 & .00271 & .00202 \\
\hline FLUID MILK & 90 & .00696 & .00567 & .00408 \\
\hline BREAD， CAKE， AND RELATED PRODUCT & 106 & .00056 & .00047 & .00036 \\
\hline BOTTLED AND CANNED SOFT DRINKS & 116 & .00106 & .00092 & .00064 \\
\hline ANIMAL AND MARINE FATS AND OILS & 121 & .00008 & .00007 & .00006 \\
\hline MANUFACTURED ICE & 124 & .00005 & .00005 & .00005 \\
\hline KNIT OUTERWEAR MILLS & 147 & .00001 & .00001 & .00002 \\
\hline APPAREL MADE FROM PURCHASED MATE & 151 & .00007 & .00008 & .00009 \\
\hline CURTAINS AND DRAPERIES & 152 & .00014 & .00015 & .00020 \\
\hline CANVAS PRODUCTS & 155 & .00002 & .00002 & .00002 \\
\hline PLEATING AND STITCHING & 156 & .00010 & .00010 & .00014 \\
\hline
\end{tabular}




\begin{tabular}{|c|c|c|c|c|}
\hline LOGGING CAMPS AND LOGGING CONTRA & 160 & .00000 & .00000 & .000 \\
\hline SAWMILLS AND PLANING MILLS, GENE & 161 & .00034 & .00035 & .000 \\
\hline HARDWOOD DIMENSION AND FLOORING & 162 & .00000 & .00000 & .000 \\
\hline SPECIAL PRODUCT SAWMILLS, N.E.C & 163 & .00000 & .00000 & .000 \\
\hline MI LLWORK & 164 & .00005 & .00007 & .000 \\
\hline WOOD KITCHEN CABINETS & 165 & .00000 & .00000 & .000 \\
\hline VENEER AND PLYWOOD & 166 & .00001 & .00001 & .000 \\
\hline STRUCTURAL WOOD MEMBERS, N.E.C & 167 & .00001 & .00001 & .000 \\
\hline WOOD PRESERVING & 169 & .00000 & .00000 & .000 \\
\hline PART ICLEBOARD & 171 & .00001 & .00001 & .000 \\
\hline WOOD PRODUCTS, N.E.C & 172 & .00011 & .00013 & .000 \\
\hline WOOD HOUSEHOLD FURNITURE & 174 & .00162 & .00214 & .002 \\
\hline WOOD PARTITIONS AND FIXTURES & 183 & .00001 & .00001 & .000 \\
\hline FURNITURE AND FIXTURES, N.E.C & 186 & .00001 & .00001 & .000 \\
\hline NEWSPAPERS & 200 & .00104 & .00103 & .001 \\
\hline PERIODICALS & 201 & .00078 & .00078 & .000 \\
\hline BOOK PUBLISHING & 202 & .00024 & .00024 & .000 \\
\hline MISCELLANEOUS PUBLISHING & 204 & .00003 & .00002 & .000 \\
\hline COMMERCIAL PRINTING & 205 & .00005 & .00005 & .000 \\
\hline TYPESETTING & 212 & .00000 & .00000 & .000 \\
\hline FERTILIZERS， MIXING ONLY & 217 & .00001 & .00001 & .000 \\
\hline TOILET PREPARATIONS & 233 & .00039 & .00039 & .000 \\
\hline FABRICATED RUBBER PRODUCTS, N.E. & 243 & .00000 & .00000 & .000 \\
\hline MISCELLANEOUS PLASTICS PRODUCTS & 244 & .00008 & .00008 & .000 \\
\hline LEATHER GLOVES AND MITTENS & 250 & .00011 & .00012 & .000 \\
\hline WOMENS HANDBAGS AND PURSES & 252 & .00026 & .00024 & .000 \\
\hline PERSONAL LEATHER GOODS & 253 & .00021 & .00020 & .000 \\
\hline LEATHER GOODS, N.E.C & 254 & .00001 & .00001 & .000 \\
\hline GLASS AND GLASS PRODUCTS, EXC CO & 255 & .00008 & .00010 & .000 \\
\hline BRICK AND STRUCTURAL CLAY TILE & 258 & .00000 & .00000 & .000 \\
\hline CLAY REFRACTORIES & 260 & .00000 & .00000 & .000 \\
\hline POTTERY PRODUCTS, N.E.C & 266 & .00000 & .00000 & .000 \\
\hline CONCRETE BLOCK AND BRICK & 267 & .00000 & .00000 & .000 \\
\hline CONCRETE PRODUCTS, N.E.C & 268 & .00000 & .00000 & .000 \\
\hline READY-MIXED CONCRETE & 269 & .00000 & .00000 & .000 \\
\hline MINERALS, GROUND OR TREATED & 276 & .00000 & .00000 & .000 \\
\hline HEATING EQUIPMENT, EXCEPT ELECTR & 307 & .00001 & .00001 & .000 \\
\hline FABRICATED STRUCTURAL METAL & 308 & .00000 & .00000 & .000 \\
\hline SHEET METAL WORK & 311 & .00000 & .00000 & .000 \\
\hline ARCHITECTURAL METAL WORK & 312 & .00000 & .00000 & 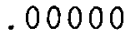 \\
\hline METAL STAMPINGS, N.E.C. & 318 & .00002 & .00003 & .000 \\
\hline PLATING AND POLISHING & 323 & .00000 & .00000 & .000 \\
\hline METAL COATING AND ALLIED SERVICE & 324 & .00000 & .00000 & .000 \\
\hline FARM MACHINERY AND EQUIPMENT & 332 & .00000 & .00000 & 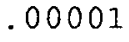 \\
\hline CONSTRUCTION MACHINERY AND EQUIP & 334 & .00003 & .00004 & .000 \\
\hline CONVEYORS AND CONVEYING EQUIPMEN & 338 & .00000 & .00000 & .000 \\
\hline INDUSTRIAL TRUCKS AND TRACTORS & 340 & .00000 & .00000 & .000 \\
\hline SPECIAL DIES AND TOOLS AND ACCES & 343 & .00001 & .00001 & .000 \\
\hline WOODWORKING MACHINERY & 349 & .00006 & .00006 & .000 \\
\hline PRINTING TRADES MACHINERY & 351 & .00000 & .00000 & .0000 \\
\hline SPECIAL INDUSTRY MACHINERY, N.E. & 352 & .00000 & .00000 & .0000 \\
\hline MACHINERY, EXCEPT ELECTRICAL, N. & 361 & .00000 & .00000 & .0000 \\
\hline ELECTRONIC COMPUTING EQUIPMENT & 362 & .00003 & .00003 & .0000 \\
\hline REFRIGERATION AND HEATING & 368 & .00016 & .00016 & .0001 \\
\hline
\end{tabular}


INSTRUMENTS TO MEASURE ELECTRICI RADIO AND TV RECEIVING SETS

TELEPHONE AND TELEGRAPH APPARATU RADIO AND TV COMMUNICATION EQUIP TRUCK TRAILERS

MOTOR VEHICLE PARTS AND ACCESSOR AIRCRAFT AND MISSILE EQUIPMENT, BOAT BUIIDING AND REPAIRING MOTORCYCLES, BICYCLES, AND PARTS TRAVEL TRAILERS AND CAMPERS MOBILE HOMES

MOTOR HOMES

SURGICAL APPLIANCES AND SUPPLIES DENTAL EQUIPMENT AND SUPPLIES SILVERWARE AND PLATED WARE GAMES, TOYS, AND CHILDRENS VEHIC SPORTING AND ATHLETIC GOODS, N.E LEAD PENCILS AND ART GOODS

SIGNS AND ADVERTISING DISPLAYS

MANUFACTURING INDUSTRIES, N.E.C. RAILROADS AND RELATED SERVICES LOCAL, INTERURBAN PASSENGER TRAN MOTOR FREIGHT TRANSPORT AND WARE AIR TRANSPORTATION

TRANSPORTATION SERVICES

ARRANGEMENT OF PASSENGER TRANSPO COMMUNICATIONS, EXCEPT RADIO AND RADIO AND TV BROADCASTING

GAS PRODUCTION AND DISTRIBUTION WATER SUPPLY AND SEWERAGE SYSTEM SANITARY SERVICES AND STEAM SUPP OTHER WHOLESALE TRADE

RECREATIONAL RELATED RETAIL TRAD OTHER RETAIL TRADE

BANKING

CREDIT AGENCIES

SECURITY AND COMMODITY BROKERS

INSURANCE CARRIERS

INSURANCE AGENTS AND BROKERS OWNER-OCCUPIED DWELLINGS

REAL ESTATE

HOTELS AND LODGING PLACES

LAUNDRY, CLEANING AND SHOE REPAI

FUNERAL SERVICE AND CREMATORIES

PORTRAIT AND PHOTOGRAPHIC STUDIO

ELECTRICAL REPAIR SERVICES

WATCH, CLOCK, JEWELRY AND FURNIT BEAUTY AND BARBER SHOPS

MISCELLANEOUS REPAIR SHOPS

SERVICES TO BUILDINGS

PERSONNEL SUPPLY SERVICES

COMPUTER AND DATA PROCESSING SER MANAGEMENT AND CONSULTING SERVIC DETECTIVE AND PROTECTIVE SERVICE
371

389

391

392

402

404

407

409

411

412

413

414

420

421

428

431

433

435

444

445

446

447

448

450

452

453

454

455

457

458

459

461

462

463

464

465

466

467

468

469

470

471

472

473

474

475

476

477

478

479

480

481

482

483
.00001

.00012

.00000

.00002

.00000

.00000

.00000

.00004

.00008

.00019

.00000

.00076

.00020

.00001

.00001

.00054

.00001

.00002

.00000

.00006

.00099

.00151

.00345

.00167

.00002

.00008

.01360

.00017

.00562

.00030

.00041

.00020

.00438

.06636

.01386

.00328

.00133

.00225

.00000

.06505

.03758

.00513

.00117

.00115

.00226

.00239

.00151

.00444

.00000

.00000

.00000

.00000

.00000

.00000

\section{.00001}

.00011

.00000

.00002

.00000

.00000

.00000

.00006

.00010

.00032

.00000

.00109

.00013

.00001

.00002

.00083

.00002

.00001

.00000

.00006

.00070

.00107

.00243

.00118

.00002

.00008

.01066

.00016

.00434

.00028

.00038

.00019

.00660

.06409

.01475

.00349

.00142

.00332

.00000

.09006

.02029

.00471

.00293

.00122

.00386

.00167

.00105

.00409

.00000

.00000

.00000

.00000

.00000

.00000
.00001

.00011

.00000

.00002

.00000

.00000

.00080

.00007

.00013

.00035

.00000

.00130

.00010

.00001

.00002

.00090

.00002

.00002

.00000

.00006

.00095

.00142

.00241

.00160

.00002

.00008

.00795

.00016

.00367

.00025

.00033

.00019

.00798

.06258

.01677

.00397

.00161

.00427

.00000

.12183

.00700

.00836

.00166

.00139

.00418

.00167

.00105

.00407

.00000

.00000

.00000

.00000

.00000

.00000 


\begin{tabular}{|c|c|c|c|c|}
\hline EQUIPMENT REPAIR AND LEASING & 484 & .00000 & .00000 & .00000 \\
\hline PHOTOFINISHING, COMMERCIAL PHOTO & 485 & .00000 & .00000 & .00000 \\
\hline OTHER BUSINESS SERVICES & 486 & .00000 & .00000 & .00000 \\
\hline ADVERTISING & 487 & .00000 & .00000 & .00000 \\
\hline LEGAL SERVICES & 488 & .00000 & .00000 & .00000 \\
\hline ENGINEERING， ARCHITECTURAL SERVI & 489 & .00000 & .00000 & .00000 \\
\hline ACCOUNTING, AUDITING AND BOOKKEE & 490 & .00007 & .00004 & .00001 \\
\hline EATING AND DRINKING PLACES & 491 & .04340 & .05258 & .04997 \\
\hline AUTOMOBILE RENTAL AND LEASING & 492 & .00008 & .00008 & .00009 \\
\hline AUTOMOBILE REPAIR AND SERVICES & 493 & .01641 & .02011 & .01788 \\
\hline MOTION PICTURES & 495 & .00027 & .00032 & .00046 \\
\hline DANCE HALLS, STUDIOS AND SCHOOLS & 496 & .00002 & .00002 & .00003 \\
\hline BOWLING ALLEYS AND POOL HALLS & 498 & .00025 & .00030 & .00043 \\
\hline COMMERCIAL SPORTS EXCEPT RACING & 499 & .00038 & .00045 & .00065 \\
\hline MEMBERSHIP SPORTS AND RECREATION & 501 & .00057 & .00068 & .00098 \\
\hline AMUSEMENT AND RECREATION SERVICE & 502 & .00263 & .00450 & .00488 \\
\hline DOCTORS AND DENTISTS & 503 & .06973 & .05089 & .04183 \\
\hline HOSPITALS & 504 & .05042 & .03680 & .03025 \\
\hline NURSING AND PROTECTIVE CARE & 505 & .00695 & .00507 & .00417 \\
\hline OTHER MEDICAL AND HEALTH SERVICE & 506 & .00495 & .00361 & .00297 \\
\hline ELEMENTARY AND SECONDARY SCHOOLS & 507 & .00002 & .00002 & .00002 \\
\hline COLLEGES， UNIVERSITIES， SCHOOLS & 508 & .00132 & .00141 & .00160 \\
\hline OTHER EDUCATIONAL SERVICES & 509 & .00008 & .00009 & .00010 \\
\hline BUSINESS ASSOCIATIONS & 510 & .00023 & .00025 & .00028 \\
\hline LABOR AND CIVIC ORGANIZATIONS & 511 & .00267 & .00284 & .00323 \\
\hline RELIGIOUS ORGANIZATIONS & 512 & .00518 & .00294 & .00530 \\
\hline OTHER NONPROFIT ORGANIZATIONS & 513 & .00090 & .00051 & .00092 \\
\hline RESIDENTIAL CARE & 514 & .00092 & .00115 & .00174 \\
\hline SOCIAL SERVICES, N.E.C. & 515 & .00775 & .00618 & .00987 \\
\hline U.S. POSTAL SERVICE & 516 & .00188 & .00182 & .00177 \\
\hline OTHER FEDERAL GOVERNMENT ENTERPR & 518 & .00105 & .00117 & .00112 \\
\hline LOCAL GOVERNMENT PASSENGER TRANS & 519 & .00005 & .00004 & .00005 \\
\hline OTHER STATE AND LOCAL GOVT ENTER & 521 & .00485 & .00446 & .00419 \\
\hline GOVERNMENT INDUSTRY & 525 & .00000 & .00000 & .00000 \\
\hline REST OF THE WORLD INDUSTRY & 526 & .00000 & .00000 & .00000 \\
\hline HOUSEHOLD INDUSTRY & 527 & .00147 & .00183 & .00277 \\
\hline INVENTORY VALUATION ADJUSTMENT & 528 & .00000 & .00000 & .00000 \\
\hline TOTAL ERACTION IN REGION & & .48908 & .46886 & .47651 \\
\hline REGIONAL FRACTION CHECK & & .99999 & 1.00000 & .99999 \\
\hline
\end{tabular}




\section{APPENDIX C}

HARNEY COUNTY STATE AND LOCAL GOVERNMENT EXPENDITURE PATTERNS FRACTION OF TOTAL STATE \& LOCAL GOVERNMENT SPENDING WITHIN REGION

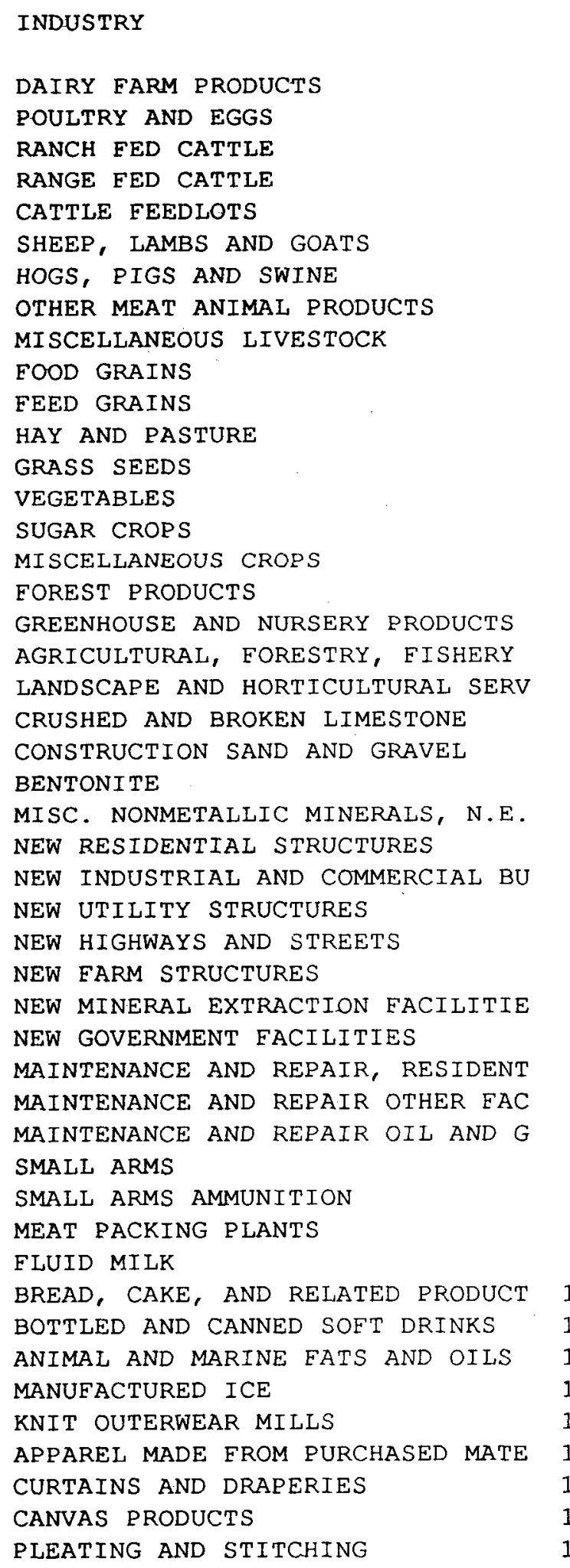

\begin{tabular}{|c|c|c|c|}
\hline & SLG-EDU & SLG-NONED & SLG-TOTAL \\
\hline 1 & .00000 & .00000 & .00000 \\
\hline 2 & .00000 & .00001 & .00001 \\
\hline 3 & .00000 & .00000 & .00000 \\
\hline 4 & .00000 & .00000 & .00000 \\
\hline 5 & .00001 & .00003 & .00002 \\
\hline 6 & .00000 & .00000 & .00000 \\
\hline 7 & .00000 & .00000 & .00000 \\
\hline 8 & .00000 & .00000 & .00000 \\
\hline 9 & .00004 & .00000 & .00002 \\
\hline 11 & .00000 & .00000 & .00000 \\
\hline 12 & .00000 & .00000 & .00000 \\
\hline 13 & .00000 & .00000 & .00000 \\
\hline 14 & .00000 & .00000 & .00000 \\
\hline 18 & .00000 & .00000 & .00000 \\
\hline 19 & .00000 & .00000 & .00000 \\
\hline 20 & .00000 & .00000 & .00000 \\
\hline 22 & .00000 & .00000 & .00000 \\
\hline 23 & .00000 & .00000 & .00000 \\
\hline 26 & .00000 & .00000 & .00000 \\
\hline 27 & .00000 & .00000 & .00000 \\
\hline 45 & .00000 & .00000 & .00000 \\
\hline 48 & .00000 & .00000 & .00000 \\
\hline 50 & .00000 & .00000 & .00000 \\
\hline 58 & .00000 & .00000 & .00000 \\
\hline 66 & .00190 & .00069 & .00124 \\
\hline 67 & .00631 & .00789 & .00717 \\
\hline 68 & .04431 & .00000 & .02008 \\
\hline 69 & .02593 & .00000 & .01175 \\
\hline 70 & .00000 & .00000 & .00000 \\
\hline 71 & .00000 & .00000 & .00000 \\
\hline 72 & .00453 & .00000 & .00205 \\
\hline 73 & .00000 & .00000 & .00000 \\
\hline 74 & .04093 & .04135 & .04116 \\
\hline 75 & .00000 & .00000 & .00000 \\
\hline 79 & .00000 & .00000 & .00000 \\
\hline 80 & .00000 & .00000 & .00000 \\
\hline 82 & .00042 & .00137 & .00094 \\
\hline 90 & .00000 & .00000 & .00000 \\
\hline 106 & .00000 & .00000 & .00000 \\
\hline 116 & .00000 & .00000 & .00000 \\
\hline 121 & .00001 & .00002 & .00001 \\
\hline 124 & .00000 & .00000 & .00000 \\
\hline 147 & .00000 & .00000 & .00000 \\
\hline 151 & .00000 & .00000 & .00000 \\
\hline 152 & .00000 & .00000 & .00000 \\
\hline 155 & .00000 & .00000 & .00000 \\
\hline 156 & .00000 & .00000 & .00000 \\
\hline
\end{tabular}




\begin{tabular}{|c|c|c|c|c|}
\hline LOGGING CAMPS AND LOGGING CONTRA & 160 & .00000 & .00000 & .00000 \\
\hline SAWMILLS AND PLANING MILLS, GENE & 161 & .00000 & .00000 & .00000 \\
\hline HARDWOOD DIMENSION AND FLOORING & 162 & .00000 & .00000 & .00000 \\
\hline SPECIAL PRODUCT SAWMILLS, N.E.C & 163 & .00000 & .00000 & .00000 \\
\hline MILLWORK & 164 & .00000 & .00000 & .00000 \\
\hline WOOD KITCHEN CABINETS & 165 & .00000 & .00000 & .00000 \\
\hline VENEER AND PLYWOOD & 166 & .00000 & .00000 & .00000 \\
\hline STRUCTURAL WOOD MEMBERS, N.E.C & 167 & .00000 & .00000 & .00000 \\
\hline WOOD PRESERVING & 169 & .00000 & .00000 & .00000 \\
\hline PARTICLEBOARD & 171 & .00000 & .00000 & .00000 \\
\hline WOOD PRODUCTS, N.E.C & 172 & .00000 & .00000 & .00000 \\
\hline WOOD HOUSEHOLD FURNITURE & 174 & .00000 & .00000 & .00000 \\
\hline WOOD PARTITIONS AND FIXTURES & 183 & .00000 & .00000 & .00000 \\
\hline FURNITURE AND FIXTURES, N.E.C & 186 & .00000 & .00000 & .00000 \\
\hline NEWSPAPERS & 200 & .00000 & .00000 & .00000 \\
\hline PERIODICALS & 201 & .00000 & .00000 & .00000 \\
\hline BOOK PUBLISHING & 202 & .00000 & .00000 & .00000 \\
\hline MISCELLANEOUS PUBLISHING & 204 & .00000 & .00000 & .00000 \\
\hline COMMERCIAL PRINTING & 205 & .00000 & .00000 & .00000 \\
\hline TYPESETTING & 212 & .00000 & .00000 & .00000 \\
\hline FERTILIZERS， MIXING ONLY & 217 & .00000 & .00000 & .00000 \\
\hline TOILET PREPARATIONS & 233 & .00000 & .00000 & .00000 \\
\hline FABRICATED RUBBER PRODUCTS, N.E. & 243 & .00000 & .00000 & .00000 \\
\hline MISCELLANEOUS PLASTICS PRODUCTS & 244 & .00000 & .00000 & .00000 \\
\hline LEATHER GLOVES AND MITTENS & 250 & .00000 & .00000 & .00000 \\
\hline WOMENS HANDBAGS AND PURSES & 252 & .00000 & .00000 & .00000 \\
\hline PERSONAL LEATHER GOODS & 253 & .00000 & .00000 & .00000 \\
\hline LEATHER GOODS, N.E.C & 254 & .00000 & .00000 & .00000 \\
\hline GLASS AND GLASS PRODUCTS, EXC CO & 255 & .00000 & .00000 & .00000 \\
\hline BRICK AND STRUCTURAL CLAY TILE & 258 & .00000 & .00000 & .00000 \\
\hline CLAY REFRACTORIES & 260 & .00000 & .00000 & .00000 \\
\hline POTTERY PRODUCTS, N.E.C & 266 & .00000 & .00000 & .00000 \\
\hline CONCRETE BLOCK AND BRICK & 267 & .00000 & .00000 & .00000 \\
\hline CONCRETE PRODUCTS, N.E.C & 268 & .00000 & .00000 & .00000 \\
\hline READY-MIXED CONCRETE & 269 & .00000 & .00000 & .00000 \\
\hline MINERALS, GROUND OR TREATED & 276 & .00000 & .00000 & .00000 \\
\hline HEATING EQUIPMENT, EXCEPT ELECTR & 307 & .00000 & .00000 & .00000 \\
\hline FABRICATED STRUCTURAL METAL & 308 & .00000 & .00000 & .00000 \\
\hline SHEET METAL WORK & 311 & .00000 & .00000 & .00000 \\
\hline ARCHITECTURAL METAL WORK & 312 & .00000 & .00000 & .00000 \\
\hline METAL STAMPINGS, N.E.C. & 318 & .00000 & .00000 & .00000 \\
\hline PLATING AND FOLISHING & 323 & .00000 & .00000 & .00000 \\
\hline METAL COATING AND ALLIED SERVICE & 324 & .00000 & .00000 & .00000 \\
\hline FARM MACHINERY AND EQUIPMENT & 332 & .00000 & .00000 & .00000 \\
\hline CONSTRUCTION MACHINERY AND EQUIP & 334 & .00000 & .00000 & .00000 \\
\hline CONVEYORS AND CONVEYING EQUIPMEN & 338 & .00000 & .00000 & .00000 \\
\hline INDUSTRIAL TRUCKS AND TRACTORS & 340 & .00000 & .00000 & .00000 \\
\hline SPECIAL DIES AND TOOLS AND ACCES & 343 & .00000 & .00000 & .00000 \\
\hline WOODWORKING MACHINERY & 349 & .00000 & .00000 & .00000 \\
\hline PRINTING TRADES MACHINERY & 351 & .00000 & .00000 & .00000 \\
\hline SPECIAL INDUSTRY MACHINERY, N.E. & 352 & .00000 & .00000 & .00000 \\
\hline MACHINERY, EXCEPT ELECTRICAL, N. & 361 & .00000 & .00000 & .00000 \\
\hline ELECTRONIC COMPUTING EQUIPMENT & 362 & .00000 & .00000 & .00000 \\
\hline REFRIGERATION AND HEATING EQUIPM & 368 & .00000 & .00000 & .00000 \\
\hline
\end{tabular}




\begin{tabular}{|c|c|c|c|c|}
\hline INSTRUMENTS TO MEASURE ELECTRICI & 371 & .00000 & .00000 & .00000 \\
\hline RADIO AND TV RECEIVING SETS & 389 & .00000 & .00000 & .00000 \\
\hline TELEPHONE AND TELEGRAPH APPARATU & 391 & .00000 & .00000 & .00000 \\
\hline RADIO AND TV COMMUNICATION EQUIP & 392 & .00000 & .00000 & .00000 \\
\hline TRUCK TRAILERS & 402 & .00000 & .00000 & .00000 \\
\hline MOTOR VEHICLE PARTS AND ACCESSOR & 404 & .00000 & .00000 & .00000 \\
\hline AIRCRAFT AND MISSILE EQUIPMENT, & 407 & .00000 & .00000 & .00000 \\
\hline BOAT BUILDING AND REPAIRING & 409 & .00000 & .00000 & .00000 \\
\hline MOTORCYCLES, BICYCLES, AND PARTS & 411 & .00000 & .00000 & .00000 \\
\hline TRAVEL TRAILERS AND CAMPERS & 412 & .00000 & .00000 & .00000 \\
\hline MOBILE HOMES & 413 & .00000 & .00000 & .00000 \\
\hline MOTOR HOMES & 414 & .00000 & .00000 & .00000 \\
\hline SURGICAL APPLIANCES AND SUPPLIES & 420 & .00000 & .00000 & .00000 \\
\hline DENTAL EQUIPMENT AND SUPPLIES & 421 & .00000 & .00000 & .00000 \\
\hline SILVERWARE AND PLATED WARE & 428 & .00000 & .00000 & .00000 \\
\hline GAMES, TOYS, AND CHILDRENS VEHIC & 431 & .00000 & .00000 & .00000 \\
\hline SPORTING AND ATHLETIC GOODS, N.E & 433 & .00000 & .00000 & .00000 \\
\hline LEAD PENCILS AND ART GOODS & 435 & .00000 & .00000 & .00000 \\
\hline SIGNS AND ADVERTISING DISPLAYS & 444 & .00000 & .00000 & .00000 \\
\hline MANUFACTURING INDUSTRIES, N.E.C. & 445 & .00000 & .00000 & .00000 \\
\hline RAILROADS AND RELATED SERVICES & 446 & .00000 & .00000 & .0000 \\
\hline LOCAL， INTERURBAN PASSENGER TRAN & 447 & .00000 & .00000 & .00000 \\
\hline MOTOR FREIGHT TRANSPORT AND WARE & 448 & .00000 & .00000 & .00000 \\
\hline AIR TRANSPORTATION & 450 & .00236 & .00389 & .00320 \\
\hline TRANSPORTATION SERVICES & 452 & .00001 & .00001 & .00001 \\
\hline ARRANGEMENT OF PASSENGER TRANSPO & 453 & .00000 & .00000 & .00000 \\
\hline COMMUNICATIONS, EXCEPT RADIO AND & 454 & .00519 & .01061 & .00815 \\
\hline RADIO AND TV BROADCASTING & 455 & .00000 & .00000 & .00000 \\
\hline GAS PRODUCTION AND DISTRIBUTION & 457 & .00000 & .00000 & .00000 \\
\hline WATER SUPPLY AND SEWERAGE SYSTEM & 458 & .00000 & .00000 & .00000 \\
\hline SANITARY SERVICES AND STEAM SUPP & 459 & .00000 & .00000 & .00000 \\
\hline OTHER WHOLESALE TRADE & 461 & .00000 & .00000 & .00000 \\
\hline RECREATIONAL RELATED RETAIL TRAD & 462 & .00000 & .00005 & .00003 \\
\hline OTHER RETAIL TRADE & 463 & .00000 & .00000 & .00000 \\
\hline BANKING & 464 & .01925 & .00000 & .00872 \\
\hline CREDIT AGENCIES & 465 & .00000 & .00000 & .00000 \\
\hline SECURITY AND COMMODITY BROKERS & 466 & .00360 & .00000 & .00163 \\
\hline INSURANCE CARRIERS & 467 & .00000 & .00000 & .00000 \\
\hline INSURANCE AGENTS AND BROKERS & 468 & .00000 & .00000 & .00000 \\
\hline OWNER-OCCUPIED DWELLINGS & 469 & .00000 & .00000 & .00000 \\
\hline REAL ESTATE & 470 & .00000 & .00000 & .00000 \\
\hline HOTELS AND LODGING PLACES & 471 & .00000 & .00000 & .00000 \\
\hline LAUNDRY, CLEANING AND SHOE REPAI & 472 & .00000 & .00000 & .00000 \\
\hline FUNERAL SERVICE AND CREMATORIES & 473 & .00000 & .00000 & .00000 \\
\hline PORTRAIT AND PHOTOGRAPHIC STUDIO & 474 & .00000 & .00000 & .00000 \\
\hline ELECTRICAL REPAIR SERVICES & 475 & .00000 & .00000 & .00000 \\
\hline WATCH, CLOCK, JEWELRY AND FURNIT & 476 & .00000 & .00000 & .00000 \\
\hline BEAUTY AND BARBER SHOPS & 477 & .00000 & .00000 & .00000 \\
\hline MISCELLANEOUS REPAIR SHOPS & 478 & .00000 & .00000 & .00000 \\
\hline SERVICES TO BUILDINGS & 479 & .00000 & .00000 & .00000 \\
\hline PERSONNEL SUPPLY SERVICES & 480 & .00000 & .00000 & .00000 \\
\hline COMPUTER AND DATA PROCESSING SER & 481 & .00000 & .00000 & .00000 \\
\hline MANAGEMENT AND CONSULTING SERVIC & 482 & .00000 & .00000 & .00000 \\
\hline DETECTIVE AND PROTECTIVE SERVICE & 483 & .00000 & .00000 & .00000 \\
\hline
\end{tabular}




\begin{tabular}{|c|c|c|c|c|}
\hline EQUIPMENT REPAIR AND LEASING & 484 & .00000 & .00000 & .00000 \\
\hline PHOTOFINISHING, COMMERCIAL PHOTO & 485 & .00000 & .00000 & .00000 \\
\hline OTHER BUSINESS SERVICES & 486 & .00000 & .00000 & .00000 \\
\hline ADVERTISING & 487 & .00000 & .00000 & .00000 \\
\hline LEGAI SERVICES & 488 & .00000 & .00000 & .00000 \\
\hline ENGINEERING， ARCHITECTURAL SERVI & 489 & .00000 & .00000 & .00000 \\
\hline ACCOUNTING, AUDITING AND BOOKKEE & 490 & .00000 & .00000 & .00000 \\
\hline EATING AND DRINKING PLACES & 491 & .00000 & .00000 & .00000 \\
\hline AUTOMOBILE RENTAL AND LEASING & 492 & .00000 & .00000 & .00000 \\
\hline AUTOMOBILE REPAIR AND SERVICES & 493 & .00000 & .00000 & .00000 \\
\hline MOTION PICTURES & 495 & .00000 & .00000 & .00000 \\
\hline DANCE HALLS, STUDIOS AND SCHOOLS & 496 & .00000 & .00000 & .00000 \\
\hline BOWLING ALLEYS AND POOL HALLS & 498 & .00000 & .00000 & .00000 \\
\hline COMMERCIAL SPORTS EXCEPT RACING & 499 & .00000 & .00000 & .00000 \\
\hline MEMBERSHIP SPORTS AND RECREATION & 501 & .00000 & .00000 & .00000 \\
\hline AMUSEMENT AND RECREATION SERVICE & 502 & .00000 & .00000 & .00000 \\
\hline DOCTORS AND DENTISTS & 503 & .00000 & .00000 & .00000 \\
\hline HOSPITALS & 504 & .00000 & .00000 & .00000 \\
\hline NURSING AND PROTECTIVE CARE & 505 & .00000 & .00000 & .00000 \\
\hline OTHER MEDICAL AND HEALTH SERVICE & 506 & .00000 & .00000 & .00000 \\
\hline ELEMENTARY AND SECONDARY SCHOOLS & 507 & .00000 & .00000 & .00000 \\
\hline COLLEGES， UNIVERSITIES， SCHOOLS & 508 & .00000 & .00015 & .00008 \\
\hline OTHER EDUCATIONAL SERVICES & 509 & .00000 & .00000 & .00000 \\
\hline BUSINESS ASSOCIATIONS & 510 & .00002 & .00000 & .00001 \\
\hline LABOR AND CIVIC ORGANIZATIONS & 511 & .00000 & .00000 & .00000 \\
\hline RELIGIOUS ORGANIZATIONS & 512 & .00000 & .00000 & .00000 \\
\hline OTHER NONPROFIT ORGANIZATIONS & 513 & .00000 & .00000 & .00000 \\
\hline RESIDENTIAL CARE & 514 & .00000 & .00000 & .00000 \\
\hline SOCIAL SERVICES, N.E.C. & 515 & .00000 & .00000 & .00000 \\
\hline U.S. POSTAL SERVICE & 516 & .00371 & .00094 & .00220 \\
\hline OTHER FEDERAL GOVERNMENT ENTERPR & 518 & .00000 & .00001 & .00001 \\
\hline LOCAL GOVERNMENT PASSENGER TRANS & 519 & .00000 & .00000 & .00000 \\
\hline OTHER STATE AND LOCAL GOVT ENTER & 521 & .00005 & .00005 & .00005 \\
\hline GOVERNMENT INDUSTRY & 525 & .55277 & .39210 & .46492 \\
\hline REST OF THE WORLD INDUSTRY & 526 & .00000 & .00000 & .00000 \\
\hline HOUSEHOLD INDUSTRY & 527 & .00000 & .00000 & .00000 \\
\hline INVENTORY VALUATION ADJUSTMENT & 528 & .00000 & .00000 & .00000 \\
\hline TOTAL FRACTION IN REGION: & & .71135 & .45918 & .57346 \\
\hline REGIONAL FRACTION CHECK & & 1.00000 & 1.00000 & \\
\hline
\end{tabular}




$$
\text { . }
$$




\section{APPENDIX D}

HARNEY COUNTY EXPENDITURE IMPACTS AGGREGATED IMPLAN MODEL OUTPUT

(Impacts in dollars per thousand dollars)

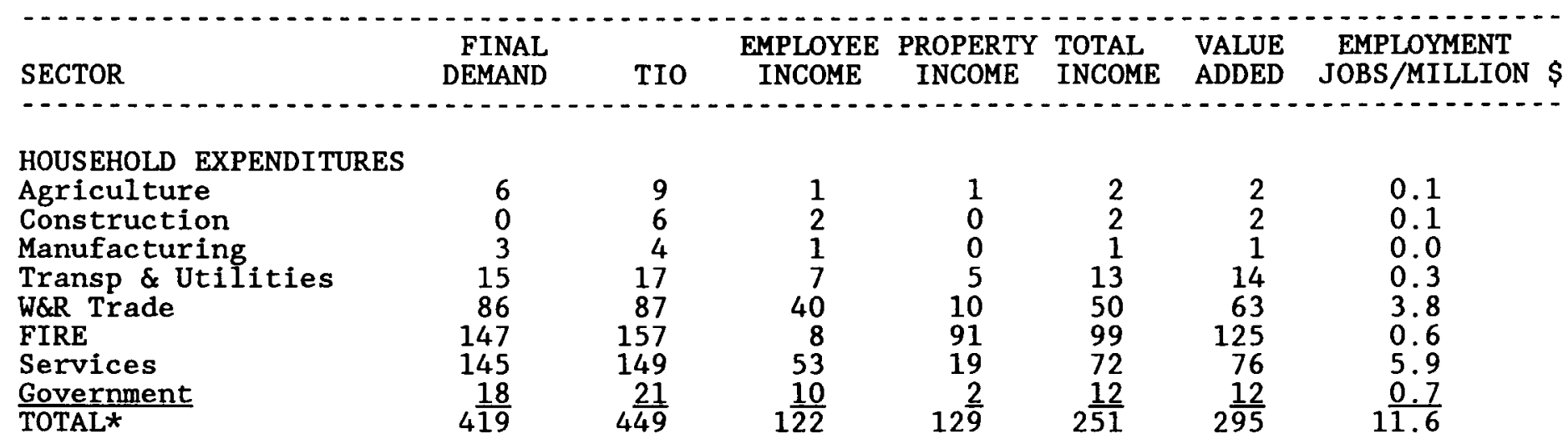

EDUCATION SERVICE EXPENDITURES

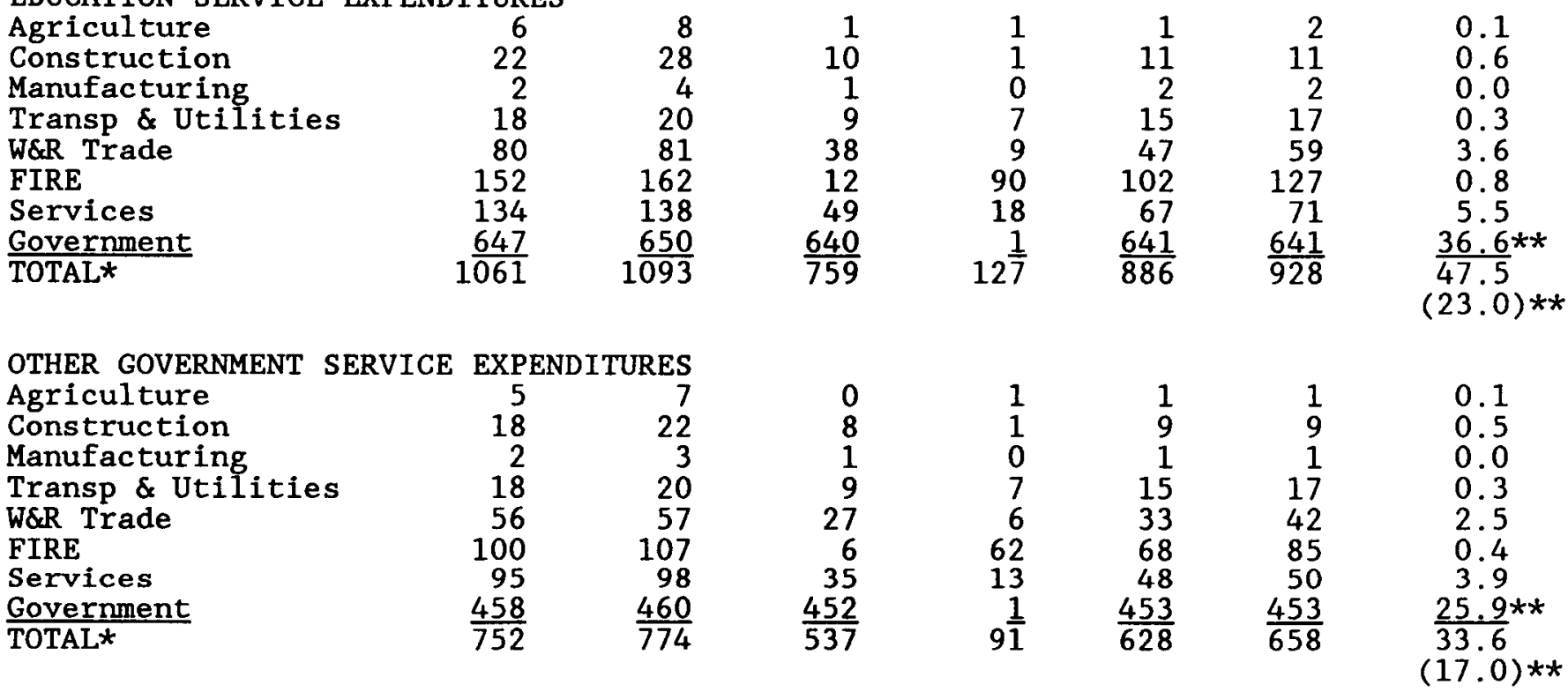

* Totals may not equal sums due to rounding errors.

** For this study, IMPLAN results for employment Impacts were adjusted downward for government employment impacts related to education expenditures. The authors felt that assuming fixed proportions of teacher salaries and associated increases in employment for teachers and other government services employees when population increases were small would be invalid.

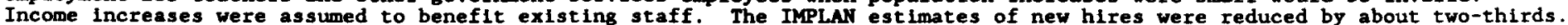


